\title{
A Holistic Strategy for Successful Photovoltaic (PV) Implementation into Singapore's Built Environment
}

\author{
Vesna Kosorić ${ }^{1,2,3}$, Siu-Kit Lau ${ }^{1, *}$, Abel Tablada ${ }^{4} \oplus$, Monika Bieri ${ }^{5}$ and André M. Nobre ${ }^{5}$ \\ 1 Department of Architecture, National University of Singapore, Singapore 117566, Singapore; \\ vesna.kosoric@gmail.com \\ 2 Balkan Energy AG, 4656 Starrkirch-Wil, Switzerland \\ 3 Daniel Hammer Architekt FH AG, 4600 Olten, Switzerland \\ 4 Faculty of Architecture, Technological University of Havana, Edificio 6, Marianao 11920, Cuba; \\ abeltablada@yahoo.com \\ 5 Cleantech Energy Corporation Pte Ltd., Singapore 049482, Singapore; moni.bieri.solar@gmail.com (M.B.); \\ andre.nobre@cleantechsolar.com (A.M.N.) \\ * Correspondence: slau@nus.edu.sg; Tel.: +65-6516-3411
}

Citation: Kosorić, V.; Lau, S.-K.; Tablada, A.; Bieri, M.; M. Nobre, A. A Holistic Strategy for Successful Photovoltaic (PV) Implementation into Singapore's Built Environment. Sustainability 2021, 13, 6452. https:// doi.org/10.3390/su13116452

Academic Editor: Domenico Mazzeo

Received: 19 May 2021

Accepted: 1 June 2021

Published: 6 June 2021

Publisher's Note: MDPI stays neutral with regard to jurisdictional claims in published maps and institutional affiliations.

Copyright: (c) 2021 by the authors. Licensee MDPI, Basel, Switzerland. This article is an open access article distributed under the terms and conditions of the Creative Commons Attribution (CC BY) license (https:// creativecommons.org/licenses/by/ $4.0 /)$.

\begin{abstract}
Based on the findings from a recent study by the authors which examined factors affecting diffusion of photovoltaics (PV), while comprehensively considering the local PV and construction industry as well as characteristics of the built environment, this paper proposes a holistic strategy for PV implementation into Singapore's built environment. It consists of (1) a multilevel mechanism framework, encompassing eleven mechanism categories of instruments and activities and (2) a general design framework including design principles, general project instructions and the main design guidelines. Relying on a survey conducted among PV experts on established mechanisms, the present study suggests that building codes (e.g., fire safety, structural safety, etc.) and initiatives and incentives related to PV/building-integrated photovoltaics (BIPV) should be the highest priority for authorities, followed by assessment of BIPV/PV properties, working toward social acceptance, conducting research projects and information exchange, and education and training activities. Considering all three pillars of sustainability, the design framework is based on the following interrelated design principles: (1) compatibility and coherence with the local context, (2) technical soundness, (3) economic viability, (4) user-centered design, (5) connecting with community and socio-cultural context, and (6) adaptability and flexibility. Despite Singapore's scarcity of land, the established design guidelines cover a wide spectrum of solutions, including PV integration into both buildings and non-building structures. The synthesis of the two interconnected and inseparable frameworks aims to create an environment conducive to long-term widespread PV integration and stimulate the deployment of BIPV, which should help Singapore and other cities reduce their dependency on imported fossil fuels, while also making them more livable and enjoyable.
\end{abstract}

Keywords: built environment; building-integrated photovoltaics (BIPV); design guidelines; façade integration; holistic strategy; low-carbon city; photovoltaics (PV); photovoltaic (PV) integration; sustainability; well-being

\section{Introduction}

Since solar photovoltaic (PV) systems are exceptionally well-suited for implementation into the built environment in comparison to other renewable energy technologies [1], and offer multiple benefits [2], researchers have, for decades, searched for solutions that would accelerate their deployment. Given their slower practical application compared to conventional rack-mounted PV [3], building-integrated photovoltaics (BIPV) have captured special attention, cutting across various disciplines. However, sustainable solutions to overcome obstacles and increase PV uptake are neither simple nor static, as confirmed by various studies. 
Aiming to promote the use of solar energy within high quality architecture, the International Energy Agency (IEA) conducted Solar Heating and Cooling (SHC) Task 41 "Solar Energy and Architecture" during 2009-2012. Among other things, the achieved results included an inventory of computer tools, recommendations for computer tool developers and guidelines for solar product developers and architects as well as an online publication of inspiring case studies [4-8]. In a study on hardware and software solutions for overcoming the barriers to BIPV in design, construction, installation, commissioning, and maintenance stages, Yang [3] highlighted the importance of the application of advanced simulation tools and energy performance monitoring platforms in practice, and encouraged stakeholder collaborations in the whole BIPV supply chain.

The strategic supply chain framework for successful BIPV diffusion, developed by Yang and Zou [9], proposes suggestions for each stakeholder group (governments, manufacturers, industry professionals, clients, end-users, and community groups) for minimizing the risks and removing the barriers. Collaboration between stakeholders is strongly suggested. The following research directions are proposed: (1) detailed cost breakdown of BIPV components, (2) lifecycle cost assessment, (3) quantifying impacts of government support and incentive policy on BIPV cost, (4) quantifying societal costs and benefits of BIPV, (5) improving professionals' knowledge to overcome technical risks and barriers, and (6) understanding the uptake process from the sociotechnical perspective.

Further, in the conceptual framework developed by Curtius [10], the barriers to and facilitators of renewable energy technologies are assessed according to three categories of adoption-related determinants: stakeholder-specific determinants, product-specific determinants, and determinants relating to the institutional framework. The recommendations for policy-makers in terms of incentives and marketers in terms of targeted communication strategies are also provided. Agathokleous and Kalogirou [11] give the following future perspectives and solutions for the full exploitation of BIPV: (1) system appearance and design configuration development, (2) realistic performance prediction with modeling tools, and (3) guidelines through regulatory regimes and BIPV policies. They emphasized the importance of collaboration between stakeholders as well as of joint development of technical training programs by the building and PV industries.

Moreover, Attoye et al. [12] have developed a conceptual framework for an educativecommunication approach to presenting BIPV. Their research findings conclude that an improved understanding of environmental and economic benefits using the developed approach can potentially facilitate and encourage BIPV adoption.

As can be noticed, the need for collaboration among stakeholders is emphasized in all mentioned studies. Heinstein et al. [13] see the tight interlocking and close networking of all stakeholders as indispensable for the expansion of BIPV, while Ballif et al. [14] identify the need for new professions bridging the gaps. Lu et al. suggest the establishment of effective communication channels among stakeholders in order to eliminate information asymmetry and disseminate research findings [15]. Moreover, Chang et al. [16] note that policymakers need to consider possibly divergent views on energy innovation policies of various actors in policymaking to avoid potential failures in policy implementation, thus indicating the complexity in formulating one set of policy mix catering to the various mindsets of stakeholders.

Given the recognized complexity of the problem, as well as the diversity and complexity of the solutions proposed in the literature, it becomes clear that long-term sustainable solutions must be holistic, dynamic, and multilevel-paying attention to interconnections between various stakeholders, activities/instruments, and processes, and taking into account the needs of the built environment and its users and, generally, of the whole community.

Accordingly, based on the fundamentals given in the recent study by the authors, "Identification of Factors Influencing Development of Photovoltaic (PV) Implementation in Singapore" [17], this paper aims to define a holistic strategy for successful PV implementation in Singapore. It addresses various environmental, economic, and social 
factors, considering relevant stakeholders' attitudes and needs, including the local PV and construction industry as well as characteristics of the built environment (see Figure 1).

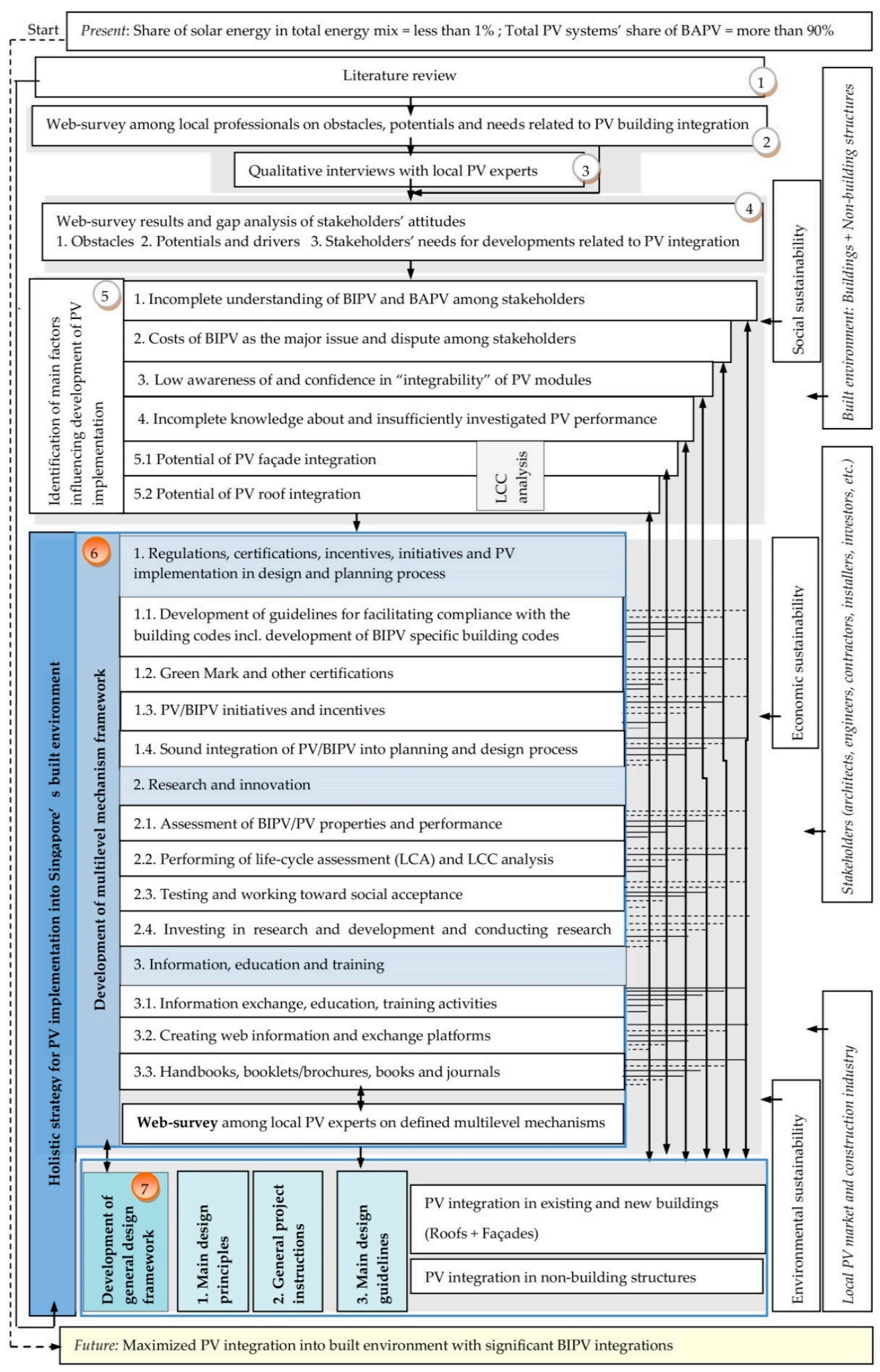

Figure 1. The schematic presentation of a holistic strategy for successful PV implementation into Singapore's built environment and methodology used for its development (full line: direct connection, dashed line: indirect connection). 
The aim of the multilevel mechanism framework is not just to eliminate factors preventing PV diffusion, but also to stimulate and enable long-term facilitating and boosting of successful BIPV and other PV implementation in Singapore. In addition to establishing eleven mechanisms, this paper prioritizes those which should be the primary focus of authorities. On the other hand, with its main design principles, general project instructions, and general design guidelines, the general design framework is intended to help create high-quality design solutions for PV implementation by providing a balanced interaction of qualities related to all three pillars of sustainability.

No longer concerned only with resources and energy, sustainability is increasingly becoming human-centric [18,19]. Accordingly, this paper points to the potentials of PV in the domain of social sustainability, including restorative and regenerative sustainability approaches, viewing PV integrations as outstanding contributors and enhancers of buildings and places [18], not only in the domain of environmental and economic aspects, but also as regards social and cultural ones. Through design recommendations and solutions, this work encourages the discovering of new user-oriented potentials of PV use within the built environment. Although viewed as solutions with multiple benefits, in the literature $\mathrm{PV}$ are primarily considered within environmental and economic dimensions, including power performance, thermal performance, optical performance (daylighting), and overall energy performance [2], including aesthetics and visual effects [1]. Among other things, the established design principles place emphasis on users' experience of the space, human enjoyment, well-being, placemaking, bonding of PV integrations with the community, and socio-cultural context. For example, in addition to users' comfort, the proposed principle of user-centered design intends to improve the quality of life and human enjoyment, while providing solutions that are both environmentally sound and collectively beneficial $[20,21]$. Further, considering that solar energy is established as a "national opportunity" for a "sunny island nation" [22], intertwined with the socio-cultural identity and civic pride, the proposed principle of connecting with the community and socio-cultural context could play a key role.

Given that Singapore's building stock, including both residential and non-residential buildings, accounts for around half of the country's electricity consumption, with less than $5 \%$ of new construction in any given year [23,24], and that the national target is to have minimum $80 \%$ of the buildings Green Mark certified by 2030 [23,25], the formulation of effective and comprehensive retrofitting strategies is crucial for improving energy efficiency and overall sustainability. On the other hand, though representing a tiny part of the overall building stock $(<5 \%)[23,24]$, new buildings which demonstrate PV integration excellence could be a significant driving force for "solarization", i.e., transformation of conventional building envelopes into multi-functional electricity producers. Also, considering that the assessed total surface area for all rooftops is $98.7 \mathrm{~km}^{2}(<14 \%$ of the total land area) [26], integrating PV into the non-building territory could help to harness the potential of the rest of the city's territory. In addition, due to Singapore's scarcity of land, public urban space, as one of the key vehicles for achieving socially, environmentally, and economically sustainable urban living, gains in importance in the emerging dense, complex, and dynamic urban conditions $[27,28]$. Hence, the implementation of PV into non-building structures and its involvement in public space design deserves special attention.

Taking into account all of the above, the strategy covers various forms of implementation of PV into the built environment, including both buildings and non-building structures. Within buildings, various BIPV and building-applied photovoltaics (BAPV) solutions are given for both roofs and façades. The two frameworks should together help widespread PV integrations and enable Singapore to fully exploit its exceptional potentials (solar energy potentials, robust real estate sector, strong economy fundaments, government commitment), all documented in [17].

The proposed holistic strategy can be used to support the goals of Singapore Green Plan 2030 [29], a whole-nation sustainable development agenda, because it deals with solutions to maximize PV deployment in Singapore. Furthermore, the strategy and both its 
multi-level mechanism and general design frameworks-through promoting PV deployment in the urban environment-can serve as an important part of city planning processes and urban energy strategy instruments [30,31], not only in Singapore, but also in other cities or similar contexts which are dealing with transition into a non-polluting and renewable electricity production system [32] to mitigate climate change and promote transition to a low-carbon society [33-35].

After the introduction in Section 1 and materials and methods in Section 2, the results and discussion related to two developed frameworks are presented in Sections 3 and 4. Conclusions are presented in Section 5.

\section{Materials and Methods}

Figure 1 provides a schematic representation of the overall methodological framework developed by the authors, which has been used in establishing a holistic strategy for PV implementation into Singapore's built environment. As shown in Figure 1, and as Lau et al. [17] noted in the recent study, the multi-stage process contained seven main phases.

The fundaments for the holistic strategy are derived based on the following first five phases: (1) literature review, (2) web-survey, (3) qualitative survey, (4) web-survey results and gap analysis of stakeholders attitudes, and (5) identification of main issues and disputes including life-cycle cost (LCC) assessments. These phases are thoroughly explained in the paper related to the first part of the study [17].

Based on a comprehensive analysis of various relevant environmental, economic and social factors (see Figure 1), and fundamentals derived in Lau et al. [17] and supported with the review of the relevant literature, a holistic strategy comprising two frameworks: (1) multilevel mechanism framework (phase 6 in Figure 1) and (2) general design framework (phase 7 in Figure 1), has been developed.

After defining mechanism categories within the multilevel mechanism framework, a web-survey has been conducted involving eight local experts with extensive experience in $\mathrm{PV}$ and BIPV. A qualitative interview with face-to-face discussions was initially planned but, due to the COVID-19 pandemic, the selected experts were contacted online and asked to participate in the web-survey. The survey examined experts' views on defined mechanisms related to their: (1) current status, i.e., level of implementation in Singapore (3-well developed, 2-slightly developed, 1-not yet developed), (2) priority to be introduced (in case of the mechanisms which are not yet developed, or are slightly developed) (3-high priority, 2-medium priority, 1-low priority), and (3) expected impact on long-term implementation of PV in Singapore (3-high impact, 2-medium impact, 1-low impact).

Besides the given activity flow through the overall methodology, the links between the general design framework and mechanism categories with the previously identified problems that they seek to address are indicated by arrows in Figure 1.

\section{Multilevel Mechanism Framework for PV Implementation into Singapore's Built Environment}

The proposed multilevel mechanism framework is established based on the conducted web-survey and qualitative interviews among local professionals together with LCC assessments performed in the first part of the study [17]. As shown in Figures 2 and 3, it includes the following three main categories of activities and instruments: (1) regulations, certifications incentives, initiatives, and PV implementation in design and planning process (paradigm shift in design and planning); (2) research and innovation; (3) information, education, and training.

The web-survey with PV experts, conducted in the second part of the study, supported the examination of established mechanisms in terms of the level of implementation, prioritization, and the expected impact on long-term implementation of PV in Singapore. The summarized results presented in Figure 2 show that experts have shown excellent alignment in priority and on the impact of different measures to support PV development. For four mechanisms, the estimated level of impact and priority is the same. The highest 
deviation between the assessed priority and impact is only 0.25 points. The focus of authorities should be on mechanisms which have an expected impact and priority above 2.5 and on measures whose current status of development is very low. Therefore, the difference between the expected impact and current status defines what should be the focus of the city authorities. Accordingly, the authorities should first focus on measures 1.1 and 1.3, i.e., building codes (e.g., fire safety, structural safety, etc.) and initiatives and incentives related to PV/BIPV, respectively, since they have the highest difference between their impact and current status, thus being priority 1 (see Figure 2). Additionally, the focus should be on mechanism categories which have a difference between their impact and current status of over 0.5 , thus presenting the priority 2 . They include mechanisms $2.1,2.3,2.4$, and 3.1, i.e., assessment of BIPV/PV properties, working toward social acceptance, conducting research projects and information exchange, and education and training activities, respectively (see Figure 2). The remaining mechanisms are of priority 3.

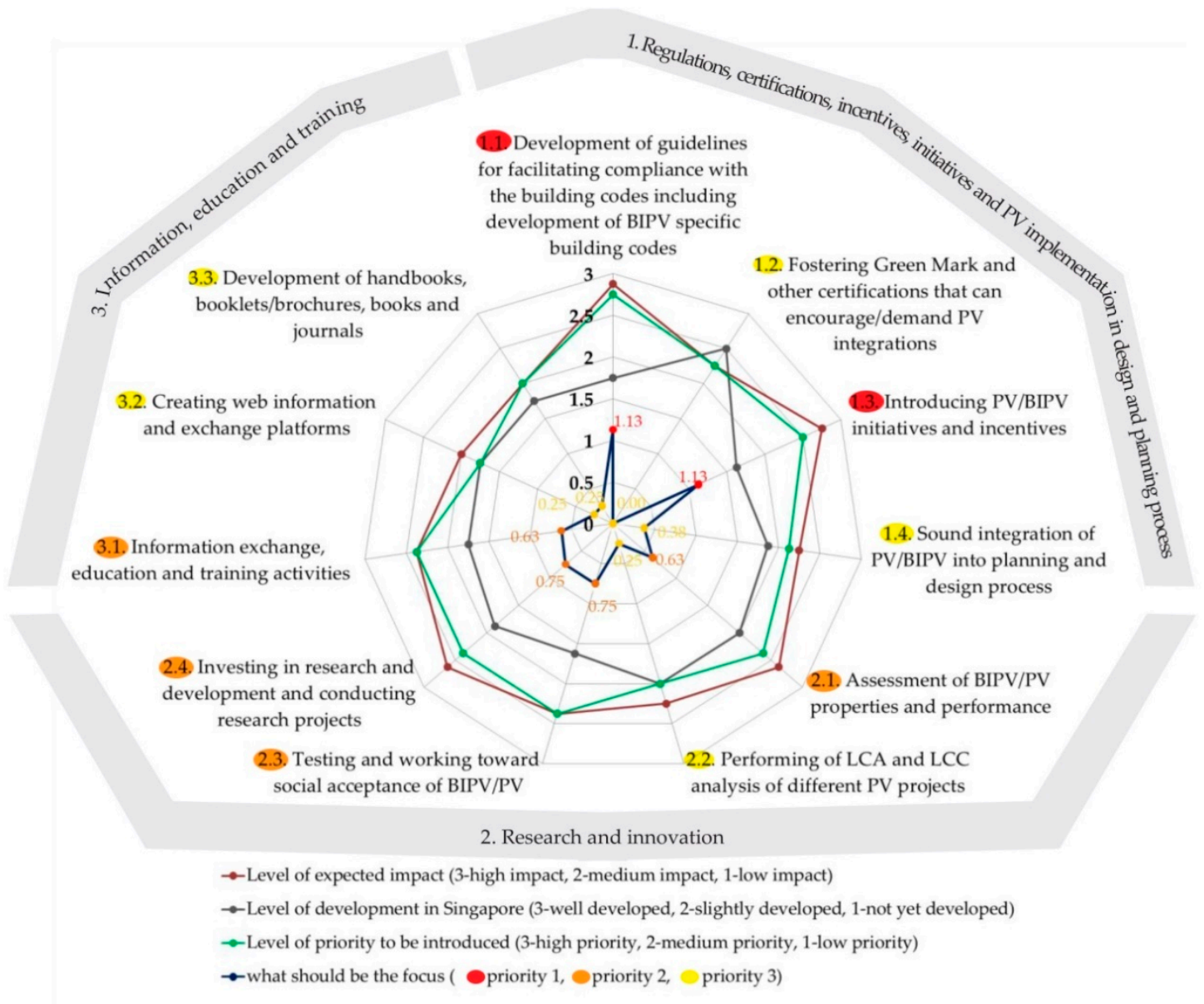

Figure 2. Eleven mechanism categories: level of expected impact, level of development in Singapore, level of priority to be introduced and what should be the focus.

The position of the mechanism framework within the overall methodology and defined strategy is presented in Figure 1. Direct and indirect links and information flows among different mechanism categories are indicated with full and dashed arrows, respectively, in Figure 3, while the relevance of interconnections within each category of actions/instruments for the corresponding stakeholder groups are specified with numbers within listed stakeholders. Taking into account all three levels, including processes, technology, and people, as shown in Figure 3, the established multilevel mechanism framework attaches a lot of importance to those interconnections and proper information flow, as well as the development of strong links, i.e., merging of PV with the building practice and technology. 


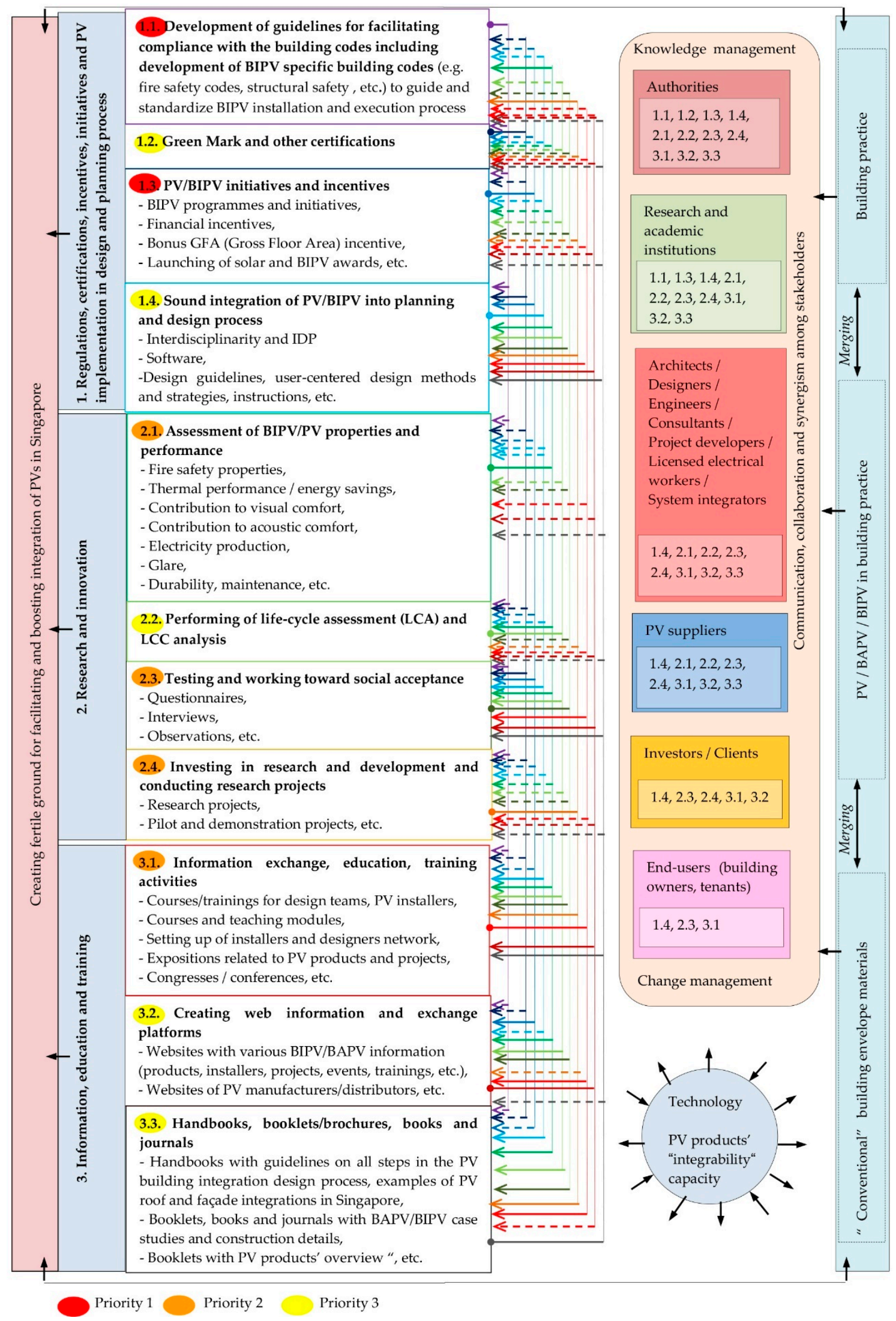

Figure 3. Multilevel mechanism framework for PV implementation into Singapore's built environment. 
Moreover, besides the involvement of all relevant stakeholders in appropriate activity/instrument categories, the framework implies active communication, collaboration, and synergism among them, favoring an integrated design process (IDP) and educativecommunication approach as important facilitators of BIPV adoption [12] and knowledge management (KM) [36] which could also help reconcile the differences in stakeholders' views and encourage adoption of PV. In order to improve the current situation in the building sector in terms of $\mathrm{PV}$ and transform it into a favorable and encouraging situation for BIPV, besides other measures mentioned, the established framework also proposes changing management (CM) [37] measures in encouragement of PV uptake in practice. The mechanism categories are explained in the following sub-sections.

\subsection{Regulations, Certifications, Incentives, Initiatives and PV Implementation in Design and Planning Process \\ 3.1.1. Development of Guidelines for Facilitating Compliance with the Building Codes Including Development of BIPV Specific Building Codes}

The experts participating in the survey deemed that the development of guidelines for facilitating compliance with the building codes, including development of BIPV specific building codes (e.g., fire safety codes [38], structural safety [39,40], etc.) (block 1.1, Figure 3), to guide and standardize the BIPV installation and execution process $[15,41,42]$ is the mechanism with the highest expected impact and, at the same time, with the highest priority to be developed (Figure 2). Therefore, this is the mechanism assigned priority 1 on which authorities should focus. In particular, experts interviewed in the first part of the study emphasize the urgency of consolidating and facilitating fire safety requirements, i.e., design and installation criteria, to allow more design flexibility (e.g., in design of PV rooftop canopies, PV façade integrations, etc.).

\subsubsection{Fostering Green Mark and Other certifications That Can Encourage/Demand PV Integrations}

The Green Mark certification, generally important for the construction practice, was ranked in the recently conducted local study of Lu et al. [15] as the second most significant driver for BIPV. The Green Mark, which is seen by experts as the most developed measure (see Figure 2), as well as other certifications (block 1.2, Figure 3), is envisaged as an important mechanism in the proposed framework. However, more holistic policies and regulatory systems related to building energy perfomances and targeting net-zero/very low energy use in buildings, already present in some European countries, also influence, directly or indirecly, the implementation of BIPV on buildings [43].

\subsubsection{PV/BIPV Initiatives and Incentives}

PV/BIPV initiatives and incentives (block 1.3, Figure 3), acknowledged as the vital driver for the expansion of BIPV [15], are measures with priority 1, based on the survey results. Despite the provided local incentives, such as the Solar Capability Scheme (SCS) and Green Mark Scheme (GMS) in Singapore [15], this mechanism is rated as the most undeveloped among eleven mechanisms, as shown in Figure 2. Hence, several survey respondents in the first part of the study proposed a bonus Gross Floor Area (GFA) incentive and launching of architectural competitions with solar BIPV awards as important incentive mechanisms [17]. Differentiation of incentives per sector (residential, institutional, and commercial) is also recommended in order to respond to their specific interests [44].

\subsubsection{Sound Integration of PV/BIPV in the Planning and Design Process}

Fostering an interdisciplinarity and integrated design process (IDP) from initial project phases, together with adequate technical support in the form of software, design guidelines, instructions, etc., is critical for sound integration of PV/BIPV in the planning and design process (block 1.4, Figure 3). Further, potentials for building information model (BIM) system integration as the platform to manage data and share information from design to building completion of PV integrations could also be explored [45]. Although the 
mechanism related to the design process is not seen as one with high priority focus (see Figure 2), the framework implies that new, user-centered design methods and strategies enabling a paradigm shift in designing of PV integrations would greatly support a longterm strategy for PV implementation in Singapore.

\subsection{Research and Innovation}

\subsubsection{Assessment of BIPV/BAPV/PV Properties and Performance}

The mechanism related to assessment of PV properties, rated as priority 2 (see Figure 2), responds directly to the identified problem of insufficiently examined PV systems' performance [17] and helps to explore the real possibilities and limits of PV technology in the construction sector. Therefore, assessment of characteristics including glare, fire safety, durability, maintenance, etc. (block 2.1, Figure 3), which were identified as concerns by the survey respondents in the first part of the study [17], could build confidence in the technology, and bridge the gap between PV and the construction sector, while enabling the merging of PV technologies with other building envelope materials in the market. Besides electricity production, other benefits of PV systems related to contribution to comfort in buildings in Singapore, have attracted the attention of scientists in recent years, who recognized the large overall potential of BIPV solutions [46], publishing more and more papers in still under-researched areas such as, e.g., ventilation and thermal behavior of BIPV $[47,48]$. Such research should be encouraged, given that, by eliminating the unknowns about the PV technology, it plays a direct role in the promotion of BIPV and offers knowledge to be fed into the design process.

\subsubsection{Performing of Life-Cycle Assessment (LCA) and Life-Cycle Cost (LCC) Analysis of Different PV Projects}

LCA and LCC assessment of various PV projects including both BAPV and BIPV in new and existing buildings (block 2.2, Figure 3) occupies a significant place among the mechanisms since it can help resolve the main identified issue of dispute among stakeholders [17], i.e., convince them of the financial soundness of BIPV and especially PV façade integrations. Particularly helpful is the LCC assessment of different design solutions within the same project, which clearly shows how different designs affect the cost-effectiveness of the project, giving clear evidence that careful design and proper decision-making minimize the costs without a negative impact on the aesthetics. LCC assessments are advisable for different kinds of projects, as shown by case studies presented in the the first part of the study [17].

\subsubsection{Testing and Working toward Social Acceptance of Various BIPV / PV}

Given that consideration of environmental, energy, and economic issues and userfocused aspects is key for the success of green buildings [49], and given that social and psychological aspects, interrelated with disputing issues (see Figure 1), also play a role [14,50], the barriers related to them need to be overcome in order to accelerate BIPV implementation. Hence, testing and working toward social acceptance, including the surveys and interviews with various stakeholders and end-users, as well as observations, are singled out as a separate mechanism in the model (block 2.3, Figure 3). Three dimensions of acceptance identified in the literature are reflected in the mechanism: (1) socio-political acceptance by the public, key stakeholders and policy-makers, (2) market acceptance by consumers and investors, and (3) acceptance/trust of the wider community [51-53]. Recently, the productive façade concept, developed by Tablada et al. [54], demonstrated how a survey among potential end-users [55] and experts was employed in the process of façade development leading to improved façade prototypes [56].

\subsubsection{Investing in Research and Development and Conducting Research Projects}

Conducting research projects (block 2.4, Figure 3), especially the applied research linking academia and industry, is the key mechanism for development and innovation and 
is also seen as the priority 2 measure according to experts (see Figure 2). Timely publishing of results and their forwarding to relevant stakeholders in the PV integration chain enables a two-way information flow and open and dynamic knowledge creation, being a critical factor for the development of the whole PV-focused field. Previous studies have also highlighted the importance of research and innovation to overcome BIPV implementation barriers and to improve collaboration and comunication channels between BIPV stakeholders [3]. The increase of $80 \%$ in public energy-related research and development investment directed to low-carbon technologies in 2019 in comparison with the prior year reflects the global awareness of the importance of investing in research and development to assure succesful implementation of new technologies and to reach energy transition goals [57].

Furthermore, demonstration projects bring PV closer to stakeholders. For example, the projects such as NUS-CDL Tropical Technologies Laboratory (T2 Lab) [54,58] and Zero Energy Building (ZEB) $[59,60]$ have the benefit of displaying various systems in one place. Besides "showcasing" technology, they offer the possibility to test and monitor different systems, providing performance data which are very helpful in the case of new technologies. After testing, the data should be translated into "lessons learned" and passed on to the construction industry and research institutions in the form of guidelines and recommendations, etc. The level of ambition and replicability of pilot projects has been found crucial for successful creation of market niches and knowledge transfer to the industry [61]. A convenient place for such projects could be colleges, schools and even kindergartens, enabling young people and kids to be in touch with solar technology.

\subsection{Information, Education and Training}

\subsubsection{Information Exchange, Education and Training Activities for Various Stakeholders}

The lack of information and awareness was identified as one of the main barriers to implementing "green" building technologies all around the world [62]. Therefore, information exchange and education and training activities for various stakeholders in the form of courses, training, and teaching modules focused on PV integration (block 3.1, Figure 3), already from early educational stages are intended to produce sound practice, with quality staff equipped with valuable knowledge and skills for working in a PVsupportive working environment [13]. This, together with congresses, conferences, and expositions, should help synergize PV with the local construction sector and create a supportive ground dominated by knowledge, learning, and information exchange. That would promote understanding of BIPV/BAPV in the professional community and fill the gaps identified on the path of development of fertile ground for PV [17].

\subsubsection{Creating Web Information and Exchange Platforms}

Similar to the previous mechanism, web information and exchange platforms (block 3.2, Figure 3) are intended to supply stakeholders with knowledge and information relevant for PV integration into the built environment, as well as to facilitate mutual understanding and stakeholder collaboration [16]. They include websites and photo/video sharing social media platforms, loaded and constantly updated with different information which is, above all, relevant to the local market and related to products, distributors and installers, projects, guidelines, events, training, etc. (such as e.g., the website of the Swiss BIPV Competence Centre [63] and the recently launched website of the Centre of Excellence for Building-Integrated PV (BIPV) at Solar Energy Research Institute of Singapore (SERIS) [64] intended to act also as a collaborative platform for stakeholders from the private and public sectors). Further, besides providing information on planning, design, and construction of PV, the websites of manufacturers and distributors of PV products could be updated with the cost-benefit development trend of installing BIPV systems [16].

\subsubsection{Handbooks, Booklets/Brochures, Books and Journals}

Handbooks, booklets/brochures, books, and journals related to PV integration, either printed or in electronic form, as the sources of knowledge in the defined framework, are 
intended to equip stakeholders with knowledge, actual information, guidelines, and recommendations in the domain of planning, design, and construction of PV (block 3.3, Figure 3). Although various handbooks (e.g., Green Handbook-Photovoltaic (PV) systems in buildings [39], Handbook for Solar Photovoltaic (PV) Systems [40], etc.) and research articles on design methodology $[50,54,56,65]$ have been published, $28 \%$ of survey respondents in the survey performed by Lau et al. [17] deem that the lack of handbooks and practical guidelines on BIPV and PV façade integrations in Singapore is an important obstacle to BIPV implementation. In addition, $74 \%$ of survey respondents think that a handbook with guidelines on all steps in the PV building integration design process is important or very important for BIPV development. It can be concluded that the development of periodical state-of-the-art handbooks and booklets focusing on the design process would be a significant contribution to BIPV development in Singapore. Such up-to-date handbooks should be technically well-substantiated, but easy to understand and in some ways appealing to a broad range of stakeholders, comprising guidelines on all steps in the PV building integration design process. The guidelines should include both realized and hypothetical projects with roof and façade PV integrations, as well as construction/installation details, clearly showing benefits of PV. Examples of successful projects from the tropics and all around the world would inspire and motivate readers. Besides techno-economic, functional, and formal-aesthetic characteristics, booklets with PV product overviews are intended to clearly present the integration capacity of PV systems, i.e., PV modules, including their possibilities in terms of customization [66] (sizes, colors, etc.), and overall recent advancements acknowledged in the literature, which should help change the perception of PV from a technical constraint to a true raw element to be taken into account from the early design stages [14]. This should help eliminate the identified obstacle related to low awareness of and confidence in "integrability" of PV modules [17].

\section{General Design Framework for PV Implementation into Singapore's Built Environment}

Figure 4 schematically presents the general design framework consisting of: (1) the main design principles, (2) general project instructions and (3) general design guidelines.

The framework relies on approaches oriented toward sustainability and goes one step further, also including restorative and regenerative approaches. Such thinking and design approaches are laying the groundwork for a future in which an ecologically sound environment, healthy society, and a vibrant economy can equally flourish [18]. This implies placing a stronger focus on human and social aspects in design thinking [18]. Accordingly, as can be noticed in Figure 4, the design framework includes both quantitative and qualitative dimensions, and besides environmental and economic aspects, the social aspect plays a crucial role within the proposed framework. Therefore, apart from being techno-economically sound, PV integrations should provide more, i.e., contribute to the health and wellbeing of occupants, enhance aesthetic, ambient, and cultural values of the built environment, reconnect people with nature, etc. With the nowadays PV technologies $[13,14]$, outstanding solutions could be achieved: from those providing protection from adverse weather conditions, e.g., in the form of walkway shelters, through the ones providing contributions to visual, thermal, and acoustic comfort in the form of diverse integrations of PV into the building envelope, to solutions enhancing pleasant multisensory subjective experiences of users and their perception of the space. The framework implies that, through enrichment of the built environment and the quality of life of individuals and the community, PV integrations would demonstrate strong power to act multifunctionally which would directly help consolidate the place of PV technologies in the construction practice. To achieve this, a wide application of bio-climatic design, biophilic design, topophilic design, salutogenic design, etc., is encouraged [18]. Accordingly, the attributes such as place, environmental consciousness, economical feasibility, social cohesion and community, arts and culture, wellbeing, communication, and education and awareness, as well as innovation and creativity, define the design vision related to PV integrations. 


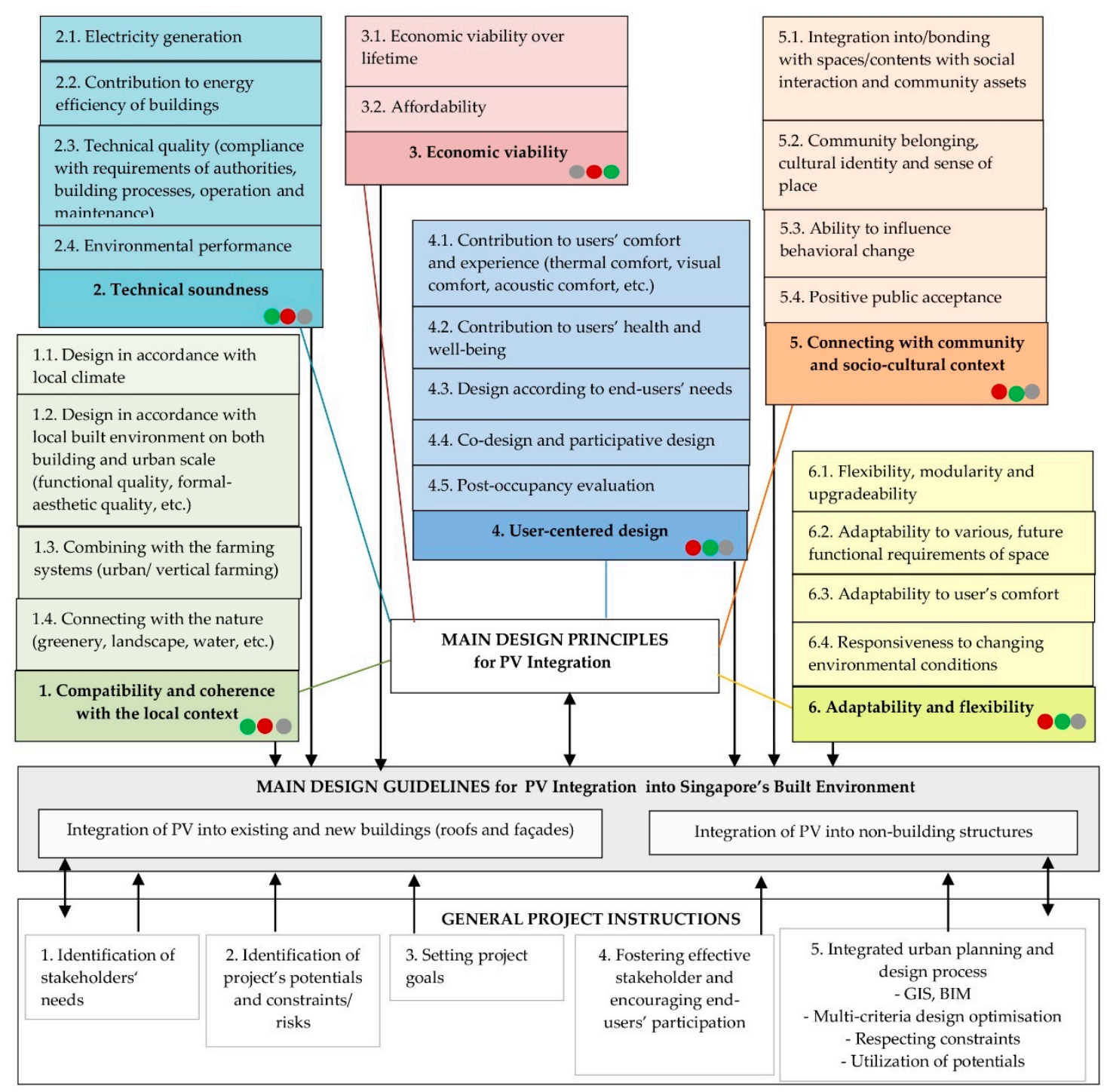

Relevance of sustainability pillars: Environmental Social Economic

Figure 4. General design framework for PV implementation into Singapore's built environment.

For example, the attribute "place" plays an important role in the design framework. The framework calls for respecting, connecting with, and designing PV integrations according to the local context, thus making a positive lasting contribution to the context. The context is comprised of a wide range of interrelated characteristics and conditions, including the physical surroundings of topography, movement patterns and infrastructure, built form and uses, weather and microclimate, the governance structures, and the cultural, social, and economic environment [67-69]. In a metaphorical sense, place carries information and memories from the past [18]. Taking this into account, the design framework implies even, for example, the understanding of aspects such as topophilia ("love of place") [70] and terraphilia ("the affective bond between people and territory which induce action in favor of development") [71].

As shown in Figure 4, in order to ensure the best outcome, the general design guidelines should be applied inseparably with the design principles and project instructions. The framework is applicable and adaptable to a wide range of projects and can well support unique design approaches that are necessary to achieve the success of each individual project. The synthesis of the general design framework (see Figure 4) and previously defined multilevel mechanism framework (see Figure 3) is intended to effectively act as a 
holistic strategy for successful PV implementation into Singapore's built environment (see Figure 1).

\subsection{The Main Design Principles for PV Integration into Singapore's Built Environment}

Six design principles and twenty-three sub-principles are defined to help reach highquality PV integration solutions, which would pave the road for PV and especially BIPV integrations. In view of the nature and interconnectedness of design principles (see Figure 4), and with a view to ensuring a comprehensive approach, simultaneous consideration of design solutions against different design principles and sub-principles is highly recommended. Furthermore, the defined sub-principles could serve as a checklist for exploring potentials in the domains related to them. However, not every PV integration has to follow each of them completely. Some types of projects and decision-making are simply not compatible with certain design sub-principles.

\subsubsection{1st Design Principle: Compatibility and Coherence of PV Integration with the} Local Context

The first design principle implies a high level of awareness and recognition of the local context in design and construction. It takes into account all characteristics and conditions defining the context [18,67-69], with a focus on the spatial and environmental context.

Compatibility and coherence arising from a well-matched PV structure refer to its ability to be in harmony with the built environment on both building and urban scales. PV systems should be placed, oriented, tilted, sized, shaped, and overall designed so as to use as much as possible the annual solar irradiation, but always in accordance with other design integration criteria. In order to ensure high-quality solutions, integration should be considered at different spatial levels, including micro-, meso-, exo- and macrosystems $[19,72,73]$. PV integrations should be designed in such a way as to properly respond to the characteristics of the context (e.g., tropical climate, the building composition grid, dimensions of envelope elements, etc.), while considering simultaneously broad integration aspects defined in the literature [6], in order to reach functional, constructive, and "aesthetic compatibility" [74], and ensure harmonious, symbiotic relation with the context [6]. It should be emphasized that harmony and symbiosis here do not necessarily imply that the PV system should be incorporated invisibly, being mimetic with the existing built environment. In fact, a full range of approaches from practice and the literature are possibly applicable, including solutions in which a PV system is added to the design or to the architectural image, or a PV system determines the architectural image or even leads to new architectural concepts [1]. Conducting surveys to investigate aesthetic acceptabilities of PV designs prior to their approval and implementation, especially in the case of aesthetically non-standard and bolder design solutions, could help ensure future acceptance of PV systems.

Hence, the key considerations within PV integration include the characteristics of the tropical climate, Singapore's high-rise and high-density built environment, and the scarcity of land and energy resources, all of which present challenges, but also potentials for innovations. Also, the special significance of urban farming as one of the "Grow Local" strategies to achieve the "30 by 30" vision of the Singapore Food Agency (SFA) [75] and Singapore's transformation from the Garden City into a "City in Nature" should be taken into account [76]. Having in mind all the above, three design sub-principles can be distinguished: (1) design in accordance with the local climate, (2) design in accordance with the local built environment on both the building and urban scale (incl. functional quality, formal-aesthetic quality, etc.), (3) combining with farming systems (urban farming, vertical farming, etc.), and (4) connecting with nature (greenery, landscape, water, etc.) (see Figure 4). Also, the first main design principle should be employed together with the design principle of technical soundness in searching for innovative design solutions for Singapore. Examples of such types of solutions are the floating PV test bed $[77,78]$ and the concept of productive façades, a promising technological response to the city's heavy 
reliance on food and energy import, which also contributes to the reduction of greenhouse gases and the increase in high-rise greenery coverage [54].

\subsubsection{2nd Design Principle: Technical Soundness of PV Integration}

PV integrations, including the system with all the equipment and construction/ supporting structure, should offer technically sound solutions, meeting primarily the criteria defined by Kaan and Reijenga, according to which the system should be longlasting and high-performing, as well as "well engineered", not only in terms of the technical necessities of PV modules (e.g., PV module safety qualifications $[79,80]$ ) and the overall PV structure (e.g., waterproofing, compliance with a set of fire safety requirements [38], etc.), but also in terms of the "elegance of the details" [1]. Furthermore, PV integrations should have the lowest possible ecological footprint and the highest possible positive impact on the environment [81].

Accordingly, the second design principle includes the following sub-principles: (1) electricity generation, (2) contribution to energy efficiency of buildings, (3) technical quality including compliance with PV system-related requirements, but also quality building processes, operation, and maintenance, and (4) environmental performance (see Figure 4).

\subsubsection{3rd Design Principle: Economic Viability of PV Integration}

As confirmed by the survey conducted by Lau et al. [17], the most critical general obstacle to widespread PV building integration, in particular BIPV, is costs. In the calculation of economic feasibility and payback period, one should take into account the cost savings from not using conventional cladding, shading devices, or roofing material in the case when PV systems replace building skin elements, as well as the impact of potential energy savings owing to PV utilization [17]. A proper treatment of PV within the design process and design optimization offers the opportunity to deliver solutions with reduced or at least well-optimized costs. In accordance with all of the above, the third design principle includes two sub-principles: (1) economic viability over lifetime and (2) affordability (see Figure 4).

\subsubsection{4th Design Principle: User-Centered Design}

The purpose of the principle of user-centered design is not only to prevent PV integrations from failing to be adopted [82], but to ensure that the design meets users' needs, thus contributing to their specific comfort requirements (visual, thermal, acoustic, security, privacy), health, and well-being. Additionally, this principle fits with "hedonistic sustainability", improving the quality of life and human enjoyment and providing collectively beneficial solutions $[20,21]$. Finally, in addition to providing information on PV performance, by providing feedback on user satisfaction and experience after the PV system has been built and occupied, the post-occupancy evaluation is of great importance for user-centered design and future projects.

Accordingly, the fourth design principle includes the following five sub-principles: (1) contribution to users' comfort and experience (e.g., contribution to thermal, visual, acoustic comfort, etc.), (2) contribution to users' health and well-being, (3) design according to end-users' specific needs, (4) co-design and participative design process, and (5) postoccupancy evaluation of PV integration (see Figure 4).

\subsubsection{5th Design Principle: Connecting with the Community and Socio-Cultural Context}

This principle includes "community-stakeholders" [20] participation in PV projects, allowing for community-integrated design $[20,83]$ and fostering and contributing to dimensions of the sense of authentic human attachment and belonging [84]. Also, it includes the bonding of PV integrations with cultural factors and attributes which are crucial for long-term community well-being and sustainability, whose potentially important role in environmental spheres has been acknowledged in the literature [85-88]. In some studies, the 
emerging "culture and sustainability" paradigm [89] has been recognized as equally important as the one placing emphasis on ecological, economic, and social sustainability [85,88].

Accordingly, this can involve a variety of different BIPV/BAPV solutions, such as semitransparent façades, skylights, shelters and diverse canopies within spaces/contents with social interaction, and public assets (e.g., city parks, community gardens, community centers, libraries, schools, venues for art and cultural activities, etc.). Thus, PV integrations can take part in creative placemaking, nurturing symbiotic relationships between arts, space, and people following some of the concepts and strategies proposed by Trivic et al. [90]. Inspiring PV integrations demonstrating feasibility and design excellence make PV technology more tangible, thus motivating stakeholders to use PV systems in their projects [91]. Further, considering PV's strong brand of "green energy", it is assumed that PV integrations providing pleasure to users, and being strongly connected with the community and socio-cultural context, coupled with appropriate information and communication campaigns, could help achieve wide-spread positive effects of motivating people towards sustainability. This means potentially encouraging positive spillover effects [92] in the form of a wider range of environmental awareness and pro-environmental behaviors [93], which are "needed in a truly sustainable energy transition" [92].

Accordingly, this design-principle includes: (1) integration into/bonding with spaces/ contents with social interaction and community assets, (2) community belonging, cultural identity, and sense of place, (3) ability to influence behavioral change, and (4) positive public acceptance. Finally, the fifth principle offers to developers the challenging, inspiring, and fruitful task of exploring how to best use this principle to maximize social benefits of PV integrations (see Figure 4).

\subsubsection{6th Design Principle: Adaptability and Flexibility}

Given the constant transformation and change in the built environment, buildings respond to changes in external and internal environments and conform to different patterns of use (e.g., size, organization, and other physical attributes of space) [94]. Due to its nature, PV systems are modular, allowing a great level of flexibility in design and specification [95], and could have the capacity to follow in a broader sense the principle of flexibility and adaptability (e.g., application of movable adaptable PV louvres). The advanced PV products and emerging approaches, such as soft-robotic-dynamic PV building envelopes for adaptive energy and comfort management [96], and design driven-dynamic pattern PV façades [97], confirm that PV technologies offer increasingly different and promising design features.

Accordingly, the sixth design principle includes: (1) flexibility, modularity, and upgradeability, (2) adaptability to various future functional requirements of space, (3) adaptability to users' comfort, and (4) responsiveness to changing environmental conditions (see Figure 4).

\subsection{General Project Instructions for PV Integration}

Since PV building integration is a complex process requiring a holistic approach and problem-solving strategies [50], and including a range of different stakeholders, project management and general PV design process-related instructions are of fundamental importance. Defined with the aim to direct the project from the beginning to the completion, general project instructions include:

(1) Identification of stakeholders' needs. After the identification of all stakeholders relevant for the project, their views, needs, interests, and expectations should be identified. For this purpose, the techniques such as focused group interviews, questionnaires, Delphi studies, etc. could be used [19];

(2) Identification of project's potentials and constraints/risks. The constraints, including those related to shading effects of the surrounding area and those related to the project's budget or timeline should be explored and detected as early as possible. Accordingly, 
the project should be directed towards feasible design solutions that comply with the project's constraints;

(3) Setting project goals. The project goals should be set based on stakeholders' needs, project's potentials and constraints/risks, and all other relevant information;

(4) Fostering effective stakeholders' communication and encouraging end-users' participation. In order to pre-empt potential problems related to stakeholders, discussed in Lau et al. [17], which could undermine the quality of the design process flow and the delivered design solution, fostering of efficient stakeholders' communication from the outset, and encouraging end-users' participation, as in the case of other types of projects $[19,98,99]$, could also play a key role in the accomplishment of a PV integration project;

(5) Integrated urban planning and design process. Due to numerous highly complex and mutually related factors involved already at the urban planning level, PV projects should be supported by multidisciplinary approach and methodologies that combine solar assessment methods and tools with other qualitative assessment approaches, methods, and tools [100], such as IDP methodologies, including multi criteria decision-analysis (MCDA) techniques and advanced platforms based on a geographic information system (GIS) [101], as well as BIM technologies facilitating PV system analytics, simulation, and optimization [102]. In this regard, in their study framed in the IEA SHC Task 51 "Solar Energy in Urban Planning", Lobaccaro et al. [31] reported on the planning process in 34 international case studies covering existing urban areas, new urban areas, and solar landscapes, including successful examples such as Solar in Halifax Regional Municipality (CA), Eco Neighborhood of Ravine Blanche in Saint-Pierre (Réunion Island), etc. According to their study, approaches, methods, and tools in urban planning play a key role in promoting the implementation of solar energy strategies [31]. Moreover, in light of the growing importance of the combined implementation of PV and agricultural systems, in case of such integrations, the estimation of photosynthetically active radiation (PAR) and Daily Light Integral (DLI) should be necessary. Likewise, as demonstrated in the recent study of Palliwal at al. [103], 3D city models could help identify suitable farming locations and have the potential for urban-scale applications. In later design stages, for example at the level of design of building envelope, design optimization could also help to adequately cope with the requirements related to various aspects and find the right balance between them while considering at the same time project potentials and constraints.

\subsection{The Main Design Guidelines for PV Integration into Singapore's Built Environment 4.3.1. Integration of PV into Buildings}

Regardless of project type, the design and construction of PV integration could follow a certain structure including the criteria and recommendations given in the relevant literature. Such structure comprises the following phases: (1) definition and identification of project objectives and challenges, (2) estimation of the potential of building/built structure for PV integration, (3) generation and optimization of PV integration design variants, (4) evaluation of PV design variants, (5) selection of the optimal PV integration design variant, (6) construction and installation, and (7) operation and monitoring $[50,66]$.

An important starting step within the design process is the site analysis. With the help of CityGML [104], on-site climate-related characteristics including solar exposure, wind pattern, dust condition, etc. could be estimated. In addition, total and partial shading conditions caused by buildings and vegetation $[105,106]$ should be detected. In this regard, indicating that a proper shading analysis during the design phase can highly improve PV systems performance by combining similarly shaded modules in the same string design, Zomer et al. [107] demonstrated that, as long as the electrical design has properly addressed any partial shading issues, even a PV installation with non-optimal combination of azimuthal deviations and tilt angles can still perform well. Further, the analysis focuses on urban and architectural quality of the context, including the architectural sensitivity of the location and visibility of the surface considered for PV integration from the public 
domain $[108,109]$. All this is critical for achieving high-quality PV integration outcomes, well embedded in the context.

In the case of planning of new buildings, due to the significant impact of the building design on the potential for solar energy harvesting and also on daylight access to buildings and PV systems as well as their surroundings, a number of building typology and morphology related parameters should be considered already at the level of urban planning and building design. Some of these parameters, analyzed in local studies [110,111], are as follows: building location on the plot, plot ratio, site coverage, building dimensions (ground floor area, height), shape i.e., inclination of building envelope parts, and orientation.

At the building level, the analysis considers the following: load-bearing capacity of the built structure, orientation and inclination of building envelope surfaces, volumetry, shading effects of building parts, and the planed PV system itself, i.e., self-shading, identification of functionally favorable areas of roof/façade for PV integration, favorable building envelope surface $\left(\mathrm{m}^{2}\right)$, capacity of the building (e.g., number of apartments, offices, etc.), electricity consumption, indoor visual and thermal comfort (e.g., in case of application of $\mathrm{PV}$ as solar shading), formal-aesthetic aspect of building envelope, mounting options and ease of installation on building envelope construction, maintenance issues and cleaning, etc. $[50,65]$.

Inevitably, and as early as possible, in order to properly conceive a set of feasible solutions, the requirements of relevant Singaporean authorities including BCA structural safety requirements, set of fire safety, i.e., SCDF requirements and URA planning guidelines, as well as Civil Aviation Authority of Singapore (CAAS) (aviation zone restrictions) [38-40,112,113], must be complied with. Further, it is of key importance to conduct the economic analysis. In order to adequately plan where and how to set up the system, a range of issues should be considered, including ventilation below PV modules, waterproof issues (e.g., for existing buildings, a mounting system causing extensive drilling of the roof should be avoided), glare impact on surrounding areas, and accessibility to users. Market research should be conducted about available PV products on the market. In certain projects, high demands, primarily of aesthetic nature, can be placed on PV integration design solutions. However, the latest generation PV components open various and interesting design perspectives, offering sophisticated solutions in the domain of new and existing, and even historic, buildings [114]. Some of these technologies, including colored Kromatix modules, are available in the local market.

Also, the needs of users and their aspirations and priorities related to PV integration should be identified and adequately considered as early as possible.

The next set of criteria that needs to be at least considered if not fully followed is that related to the quality of solar architectural integration [6,65], comprising functional and constructive, as well as formal-aesthetic criteria taking into account the project's geometry (position and dimension of PV field), materiality (visible materials, surface texture, colors), and modular pattern (size, shape of PV modules, jointing types) [6]. This helps to achieve a successful, well-thought-out PV integration and good client satisfaction, thereby contributing to greater acceptance of PV technology [1].

Given the complexity of decision-making within a PV design and the fact that the optimal solution is not necessarily the one with the highest possible generation of electricity, but rather the one that meets different, often conflicting requirements, from techno-economic ones, including those related to approval from the Singaporean authorities for the solar PV installation [113], e.g., SCDF requirements, to those related to aesthetics-the design optimization and utilization of MCDA methods and tools play the key role in design of PV systems $[50,54,65]$. Accordingly, the design process should look for long-term optimal user-oriented solutions, which can compensate, with other functional-aesthetic advantages, for their lower techno-economic performance compared to other better techno-economic performing solutions. For example, as Zomer et al. [107] have shown in their study, in the tropics, rooftop BIPV systems can perform with relatively small losses while being much more aesthetically appealing, compared to optimally-oriented and tilted BAPV solutions. 
Also, through defining the criteria weights in the MCDA methods, these methods help decision makers to reconsider priorities and correctness in decision making.

Finally, the fundaments in the form of concrete design solutions are derived for PV integration into: (1) roofs and (2) façades on existing and new buildings in Singapore.

\section{PV Roof Design Solutions}

Based on LCC assessments performed by Lau et al. [17] showing positive economic performance of roof canopies, we suggest that all new buildings should have PV on the roof in some form or, at the very least, should have such rooftop's spatial-functional organization and a load-bearing capacity that will allow easy installation of PV in the future. For example, to further this goal, HDB introduced solar-ready roofs (see Figure $5 b$ ) enabling PV modules to be easily installed and maintained [50,115]. Also, we strongly suggest that, wherever possible and beneficial, implementation of PV onto roofs of existing buildings should be considered. Relying on the conclusions derived in Lau et al. [17] and the thoroughly researched literature, we find that various design solutions could be considered for implementation onto roofs of existing and new buildings. Classified by the role of PV, the main types are listed and illustrated with some examples in Figure 5. Undoubtedly, in deciding on the design solution, the emphasis should be placed on compliance with SCDF, URA, and BCA requirements and guidelines, as well as on spatial, structural, functional, and formal-aesthetic aspects of the building and the roof itself, while the cost analysis plays an important role.

(1) BIPV rooftop canopies.

BIPV rooftop canopies (see Figure 5a-f) offer multiple design possibilities. However, depending on the design, BIPV canopies could consequently result in increased GFA. Therefore, they may have limited use in the case of some buildings (especially in the case of existing buildings), primarily due to the challenges related to URA and SCDF requirements as well as limited suitability of those buildings for PV installation (e.g., unfavorable functional organization, structural issues, etc.). However, in the cases of some other buildings, they may bring multiple benefits, serving as weather (sun/rain) shelters, or potentially offering pleasant places for sitting and relaxing such as swimming pools, gardens, etc. For example, a local built example of that is the PV installation on the rooftop of Hospital Khoo Teck Puat (Figure 5e).

The "PV Sky Garden" (see Figure 5c), the concept developed by Kosoric et al. [65], features an appealing structure composed of semi-transparent PV modules designed to be perforated with small openings ("missing" PV modules) for a visual effect, as well as for natural ventilation purposes. The concept features planned rainwater harvesting for rooftop garden irrigation, cooling of PV for their better performance, and improving the thermal comfort of the space beneath, as well as creating a pleasant ambience-if flowing of water is visually exposed, the solution shows high contextuality by symbiotically using three of Singapore's important resources: sun, greenery and rain. The concept has potentials for development into modular canopies which are very lightweight, easy to (de)mount and economically affordable. Their design can be further optimized (e.g., proper utilization of opaque/semi-transparent PV modules to enable proper transmission of light, etc.) to adjust to the specifics of the project.

Further, in light of the special significance of urban farming in Singapore [75], potentials and technological solutions for integrating PV canopies combined with farming systems in the form of agrivoltaic rooftop systems and various roof gardens (see Figure 5f) should be urgently explored. 


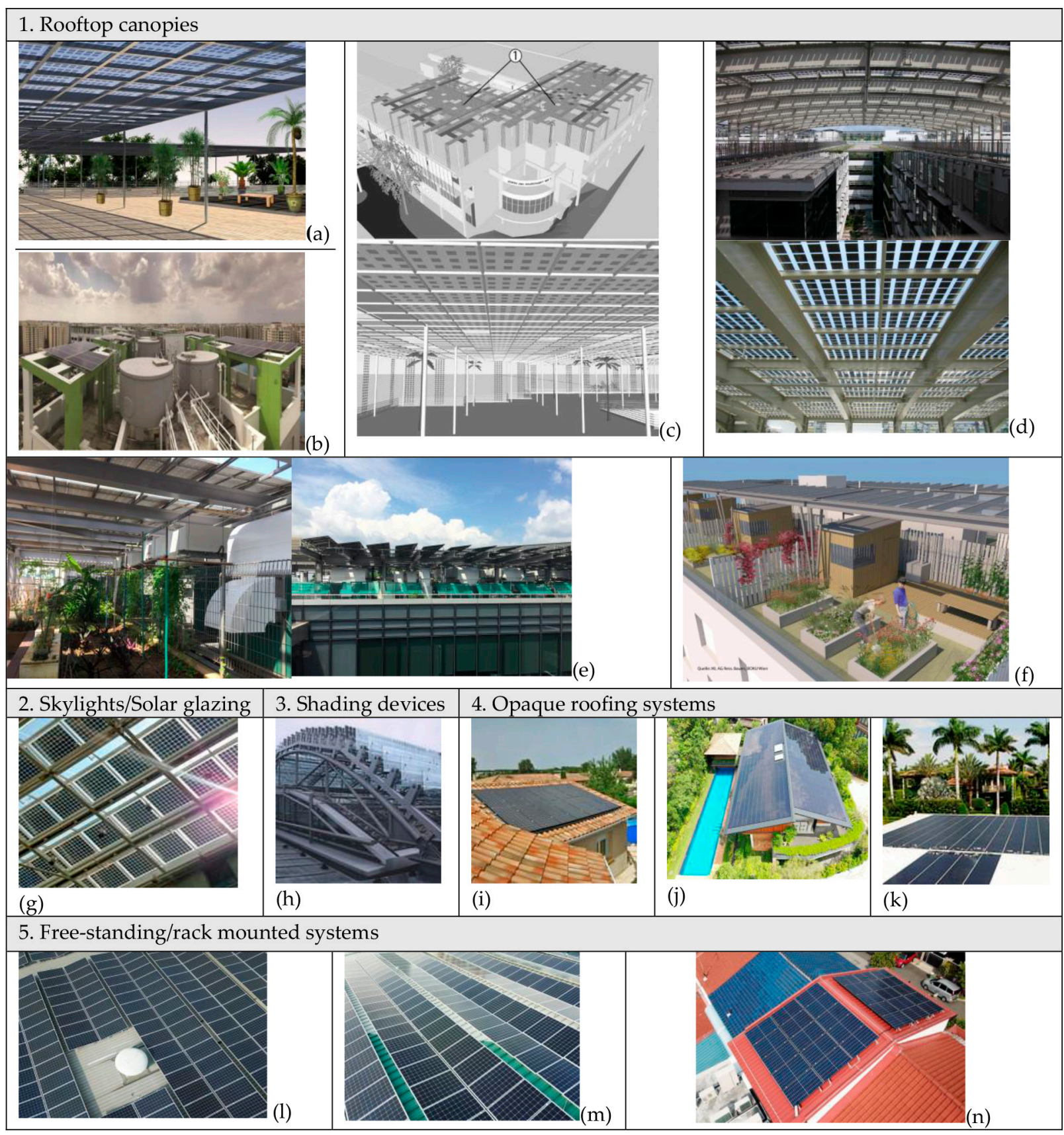

Figure 5. BIPV /BAPV roof designs: (a) rooftop canopy (by author: Vesna Kosorić); (b) solar-ready roof-Punggol Edge BTO project (Housing \& Development Board (HDB)) [50,115]; (c) rooftop envelope "PV Sky Garden" [65]; (d) CleanTech Park-1 canopy, Phoenix Solar Pte Ltd., Singapore; (e) PV canopy on Khoo Teck Puat Hospital, Singapore; (f) PV rooftop garden- "PV Rooftop Garden" project in Vienna (by Institute for Structural Engineering (IKI), AG Ressourcenorientiertes Bauen, BOKU Wien) [116]; (g) skylight ("Solar skylight", National Academy of Sciences building in Washington, DC, by GPA Photo Archive/Tim Brown, 2016, CC BY-NC 2.0 [117]); (h) shading devices—Colt louvre system ("Ministry of Justice Building, Berlin", by Colt International Limited/Darren Civil; Colt Tollfab-Victoria (Artist), 2010, CC BY-NC-ND 2.0 [118]); (i) framed in-roof system ("Panneaux photovoltaïques", by David TREBOSC, 2007, CC BY-ND 2.0 [119]); (j) full roof solution-Cornwall Gardens, Guz Architects + Energetix Pte Ltd.; (k) flexible solar roofing ("Thin Film Flexible 003", by david westmore, 2008, CC BY-SA 2.0 [120]); (1) BAPV on concrete roof, KSL Commercial warehouse project, Singapore, Energetix Pte Ltd.; (m) BAPV on metal sheet roof, SAFRA Mount Faber, Singapore, Energetix Pte Ltd.; (n) BAPV on sloped roof with tiles, Terang Bulan Avenue residential project, Energetix Pte Ltd. (Photo Credit for: (e): Abel Tablada; (d,j, $1-\mathbf{n})$ : Christophe Inglin, Energetix Pte Ltd. [121]). 


\section{(2) BIPV skylights/solar glazing.}

BIPV skylights/solar glazing (see Figure 5g), replacing the traditional roof glazing and external louvers, and providing the proper daylighting control are suitable for almost any shape of roof (flat, sloped, etc.) [122]. However, due to their specificity, they are more suitable for new buildings. Besides their benefits related to electricity generation and visual/thermal comfort, it is precisely varying patterns of light and shadows throughout the daytime created by the light entering through PV modules that make BIPV skylights very suitable for application in commercial, administrative, medical, and other institutional buildings [123]. Therefore, they can create a lively ambiance improving the overall users' experience of the space.

\section{(3) BIPV shading devices.}

Having the potential to reduce heat gain and to improve daylighting conditions in the interior, PV in the form of BIPV shading devices (see Figure $5 \mathrm{~h}$ ) are applicable over atria or skylights, e.g., on commercial buildings, office buildings, and other institutional buildings. Therefore, they can provide the visual effect of interchange of light and shadows during the day, thus greatly improving the interior and enriching the users' experience of space.

\section{(4) BIPV opaque roofing system.}

Related to various types of BIPV roofing materials, including in-roof mounting system, full roof BIPV solutions, flexible PV products and solar tiles, differing in the way they are laid on the roof, as well as in terms of other technical and also formal-aesthetic characteristics, BIPV opaque roofing systems (see Figure 5i-k) are applicable to sloped, rounded, and even, in the case of flexible products, flat roofs. Unlike in-roof mounting systems (see Figure 5i), in the case of the full roof solution, as shown in example of Cornwall Gardens project, a small detached house in Singapore (see Figure 5j), PV do not represent an "insertion" within an already defined surface but serve as a dominant factor of design involving both aesthetic and functional/constructive integration [122]. However, in tropical regions and for the summer conditions in temperate climates, a ventilated air gap is recommended to increase PV performance and to reduce heat transfer to the roofing layers under the PV cells and hence to the indoor space [124]. Flexible PV (see Figure 5k), usually attached as PV flexible laminates in a building element such as watertight membranes, BIPV, or directly applied onto the complete roof, e.g., flat roof as BAPV, are characterized by flexibility of form and ease of installation.

\section{(5) Free-standing/rack mounted PV installations.}

BAPV / BIPV free-standing/rack mounted PV installations (see Figure 5l-n) on flat and sloped/curved roofs, if applied according to a widely used, simple, and inexpensive methodology [125], merely imply fastening clipping elements onto roof metal sheets or roof tiles, or assembly of metal ballasted structures onto concrete-based rooftops. These solutions usually involve optimizing PV modules for maximum energy production, with aesthetic priorities being rather in the background. However, given that roofs, as the "fifth façade", have a significant role in Singapore's high-rise urban environment, precisely due to the "higher" rooftop visibility from the higher floors of the surrounding buildings, the aesthetic aerial image of created PV patterns on rooftops should also be taken into consideration as shown in several projects by Energetix Pte Ltd. in Singapore (see Figure 6). Although usually referring to retrofits, BAPV free-standing/rack mounted PV installations are also suitable solutions on roofs of new buildings, if estimated that for certain reasons, e.g., energy generation, costs, or even aesthetics, they are more suitable than BIPV solutions. For example, this is the case where PV are not intended to blend with the building, but are intentionally "separated", i.e., added to another building part. Given the importance of the roof as the fifth façade, attention should also be paid to their areal image (see Figure 6), and the aesthetic capacity of building "added" PV solutions. 


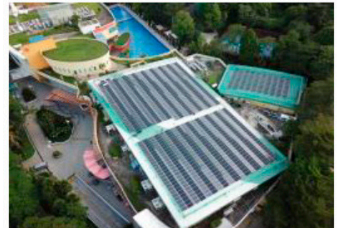

(a)

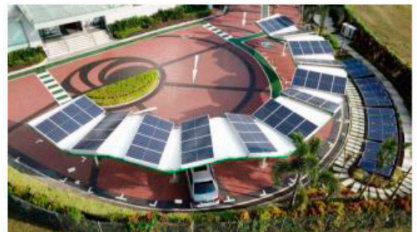

(b)

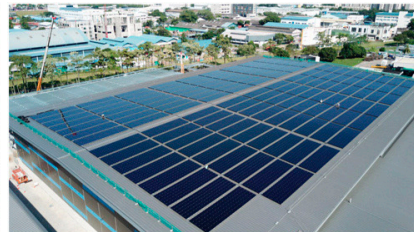

(c)

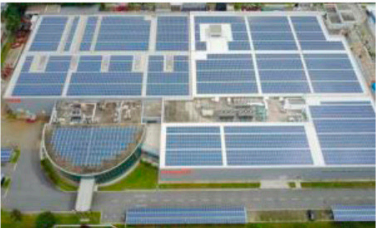

(d)

Figure 6. Areal image of BAPV roof designs, Projects by Energetix Pte Ltd. in Singapore: (a) SAFRA, Mount Faber; (b) Schneider Electric Singapore Pte Ltd.; (c) Hanwell Holdings; (d) Yamazaki Mazak factory. (Photo Credit for (a) to (d): Christophe Inglin, Energetix Pte Ltd. [121]).

\section{PV Façades Design Solutions}

The performed LCC assessments in the first part of the study [17] demonstrated the potentials of PV façade integrations. However, as noted by Lau et al. [17], different types of projects may differ significantly in economic viability. Lau et al. [17] have shown that costs savings from not using conventional façade elements (e.g., cladding, etc.), as well as reduced air conditioning needs, have a direct positive influence on the economic feasibility of PV façades. Based on discussions with PV experts, it follows that the application of PV could be economically reasonable even on existing HDB building façades, already as the replacement of paint finishes. Plaster and paint finishes of HDB building façades need to be repainted every five years. For example, taking into account the painting cost of SGD $50 / \mathrm{m}^{2}$, this results in costs of SGD $300 / \mathrm{m}^{2}$ in 30 years, which possibly coincides with the cost and warranty of PV cladding. In addition, PV modules produce electricity and lower indoor air temperature, thus resulting in reduced air conditioning in the apartments.

Given the lower energy production capacity of the façade compared to the roof [17], the application of PV modules on façades may be driven by needs such as reducing users' thermal/visual discomfort and increasing the appeal of the building through "green" façade solutions. Relying on findings from the study of Lau et al. [17] and the literature review, various design solutions, listed in Figure 7 and explained below, are proposed for PV integration into façades.

\section{(1) BAPV/BIPV façade cladding.}

BIPV/BAPV cladding solutions (see Figure 7a-g) could result in an appealing look of buildings. If functionally and aesthetically reasonable, PV modules do not have to follow the vertical inclination of the façade, enabling higher energy yield (see Figure 7e). According to Kosoric et al. [50], visually dominant, aesthetically varied PV integration designs could promote individual identity of Housing \& Development Board (HDB) blocks and, apart from fulfilling environmental and economic goals, could also promote social sustainability and motivate sustainable behavior. This coincides with the tender related to the development of a PV vertical system for HDB blocks, launched at the end of 2017, which, besides strong technical requirements (effectiveness of the design, easy (dis)mounting and maintenance, etc.), also required that the system should be aesthetically pleasing and improve visual identity.

Given the sporadic PV integration on façades in Singapore, the attractive, wellintegrated PV on the façade, especially if applied onto well-known buildings, or built near public and highly visited areas (e.g., MRT stations), can be encouraging and effectively bring these systems closer to practice. Thanks to nowadays PV technologies, BIPV cladding solutions offer different aesthetic solutions, in different colors, as also shown in design created with colored Kromatix PV modules (Facade Global Master Pte Ltd., Singapore) in Figure 7c. 


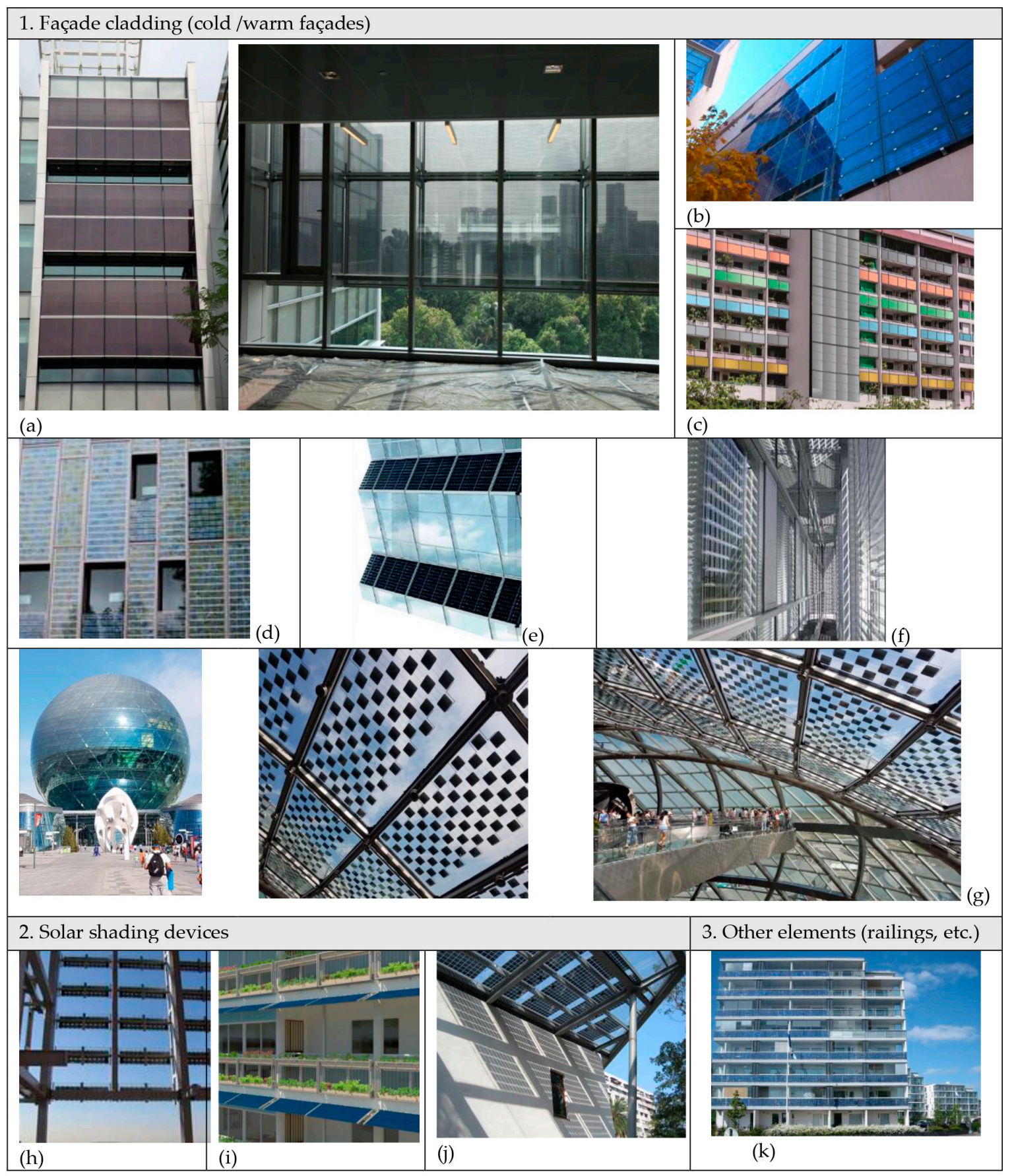

Figure 7. BIPV /BAPV façade designs: (a) cold façade as the semi-transparent solar shading element-Façade of CREATE, Phoenix Solar Pte Ltd., Singapore; (b) opaque cold façade ("BIPV solar-façade", Photovoltaic solar facade on a municipal building, Social Services Centre Jose Villarreal, located in Madrid (Spain), by Hanjin, 2013, CC BY-SA 3.0 [126]); (c) PV colored façade (design by author: Vesna Kosorić); (d) opaque warm façade-solar façade Fondation Abbé Pierre, Paris; Ertex Solartechnik GmbH ("Solar facade”, by La Citta Vita,2011, CC BY-SA 2.0 [127]); (e) inclined warm façade [128]; (f) semitransparent warm façade-Fronius Pettenbach project, by Ertex Solartechnik GmbH + arch. Benesch Stögmüller [129]; (g) semi-transparent warm façade, Kazakhstan; (h) solar shading-Colt shading systems ("One River Terrace (Battery Park), NY", by Colt International Limited, 2007, CC BY-NC-ND 2.0 [130]); (i) productive façade [56]; (j) overhang on the building entrance ("Taipei Public Library Solar LEO House BIPV", by Littleha, 2011, CC-BY-2.5 [131]); (k) railings—block of flats in Latokartano ecological housing area in Viikki area, Helsinki ("Solar panels integrated in a block of flats in Viikki Helsinki Finland”, by Pöllö, 2008, CC-BY-3.0 [132]). (Photo Credit for (a,g): Christophe Inglin, Energetix Pte Ltd. [121]). 
Typically presenting a continuous building envelope system, BIPV warm façade [122], besides being able to fulfil all building envelope requirements including load bearing, weatherproofing, and thermal, visual, and acoustic comfort, offers diverse formal and aesthetic possibilities (see Figure $8 \mathrm{~d}-\mathrm{g}$ ). Acknowledged as a promising design catalyst of energy efficient envelopes of highly glazed high-rise buildings $[128,133]$, semi-transparent BIPV have good energy saving potential according to the study of $\mathrm{Ng}$ et al. [46]. However, due to their complexity, they require a variety of window-wall-ratios and other design optimizations to achieve the highest energy and other benefits [46].

Finally, similar to roofs, the possibility of combining PV and building integrated architecture (BIA) should be urgently explored, which would contribute to food security and bring the nature to users, thus also improving indoor comfort and worker productivity [134].

\section{(2) BIPV solar shading devices.}

On glazed/window areas or balconies/loggias, BIPV solar shading devices (see Figure $7 \mathrm{~h}-\mathrm{j}$ ) in the form of different solar shading elements, productive façades $[54,56]$ or a canopy around the roof-edge or at the entrance to the building, are also applicable on both existing and new buildings.

On large glazed/window areas or balconies/loggias with no solar shading elements, experiencing thermal and visual discomfort due to high amounts of solar irradiation, BIPV shading devices, whose potentials have been locally examined in studies of Wittkopf et al. [60], Saber et al. [135] and Ong and Tablada [136], could be used to reduce solar gains in the building, thereby increasing the thermal and visual comfort of occupants. For example, large energy consumption, large surfaces of glazed façades, and a favorable relation between the building functions and electricity generation [137-139], make office buildings suitable for application of BIPV solar shading devices. However, they can be applied on almost all building types including residential buildings, school buildings, commercial buildings, medical buildings, etc., and the multi-objective optimization in their planning might play a crucial role to achieve the balance of building performance factors influenced by PV integrated shading devices, such as cooling energy consumption, artificial lighting energy consumption, electrical energy generation, indoor visual comfort, and others [139].

If the design/construction of the building envelope allows, productive façade systems that integrate PV, such as shading devices and farming planters [54,56] (see Figure 7i), could be considered for integration into existing and new façades, on windows, or on parts of balconies/loggias. According to Tablada et al. [56], preferable designs range from PV modules in the form of a single continuous and relatively narrow overhand for north and south façades, to a multiple-layer PV system for east and west façade orientations [56]. Apart from improving indoor comfort by enabling the inhabitants of dense urban environments to produce food by themselves, those systems could have multiple health and well-being benefits [140-142].

Applied in the form of a canopy around the roof-edge or at the entrance to the building, PV overhangs (see Figure 7j) play a role in weather protection (sun/rain), while also having a decorative role by the aesthetic accentuation of the entrance or the roof-edge.

(3) Various other BAPV/BIPV elements-“accessories" (railings, balconies, balustrades, etc.).

Besides producing electricity, ensuring the safety rail, and providing privacy, with a variety of $\mathrm{PV}$ products ranging from different opaque to semi-transparent ones, various BIPV (BAPV) elements-“accessories” (railings, balconies, balustrades, etc.) integrated into balcony railings (Figure 7k), loggia rails, or stair railings, present aesthetically pleasing solutions applicable to a wide range of design concepts.

\subsubsection{Integration of PV into Non-Building Structures}

When integrated into the public space, $\mathrm{PV}$, if carefully designed considering six design principles, could play a significant role in the overall experience of the city and become 
a very important factor within a holistic strategy for PV implementation in Singapore. Accordingly, various PV canopies over pedestrian walks, bicycle pathways, and open areas or visual/acoustic barriers can contribute directly to the spatial variety and environmentally friendly design and user comfort-HARDware attributes that are crucial for the nodal, spatial, and environmental performance of urban spaces [27,28]. Similarly, various PV seating amenities and unique outdoor sculptures could enrich social activities and identitySOFTware attributes that focus on the relationship between people and space and its social and perceptual values $[27,28]$. Finally, PV implemented in various information signs and boards, street lighting, refreshment points, and safety and visual barriers (fences, etc.) may ensure provisions and safety-ORGware attributes which refer to operational and management aspects of the public space $[27,28]$.

Based on the literature, offering a variety of design possibilities, a wide range of nonbuilding structures [143-145] are proposed for PV implementation and listed in Figure 8.

(1) PV canopies.

In the form of shelters over open space, areas used for sports, leisure and recreation purposes, walkways, bicycle paths, and parking areas, designed in different forms and materializations, PV canopies (Figure 8a-f) provide protection against solar radiation and rain, thus enabling users to feel pleasant and comfortable when walking, cycling, playing, and spending time in open spaces. Various design solutions should be explored, including large canopies between buildings and those that even connect buildings as shown in the example of the design concept in Figure 8c.

\section{(2) $P V$ as urban equipment.}

In the form of various bus shelters, information signs and boards, street lighting, seating amenities, kiosks (pavilions, refreshment points, etc.), safety, visual and acoustic barriers (fences, etc.), and outdoor art sculptures, various PV urban equipment (Figure 8g-(i.2)) makes public space comfortable, attractive, and inspiring [146], thus contributing to the establishment of livable spaces as a "vital ingredient of successful cities" $[147,148]$. In this regard, presenting a "fusion of nature, art and technology", Supertrees in Gardens by the Bay (Figure 8(i.1,i.2)) are good examples, reflecting well the defined design principles. PV cells are embedded into their canopies for lighting up, while orchids, ferns, bromeliads, and flowering vines grow on panels on their trunks [149].

(3) Transport facilities.

Different infrastructure areas should be investigated and considered for PV implementation. For example, they include covered railway tracks of the Mass Rapid Transit (MRT), with a preliminary SERIS' estimated length of $56 \mathrm{~km}$ above ground, which is due to its small width and the elevated (and exposed) construction recognized as a suitable area for PV integration [150], as well as covered bicycle paths (Figure 8j). They could further include different solar-powered equipment (solar traffic signs and signals, solar-powered petrol pumps, PV sound barriers (Figure 8k), etc.) [151]. 


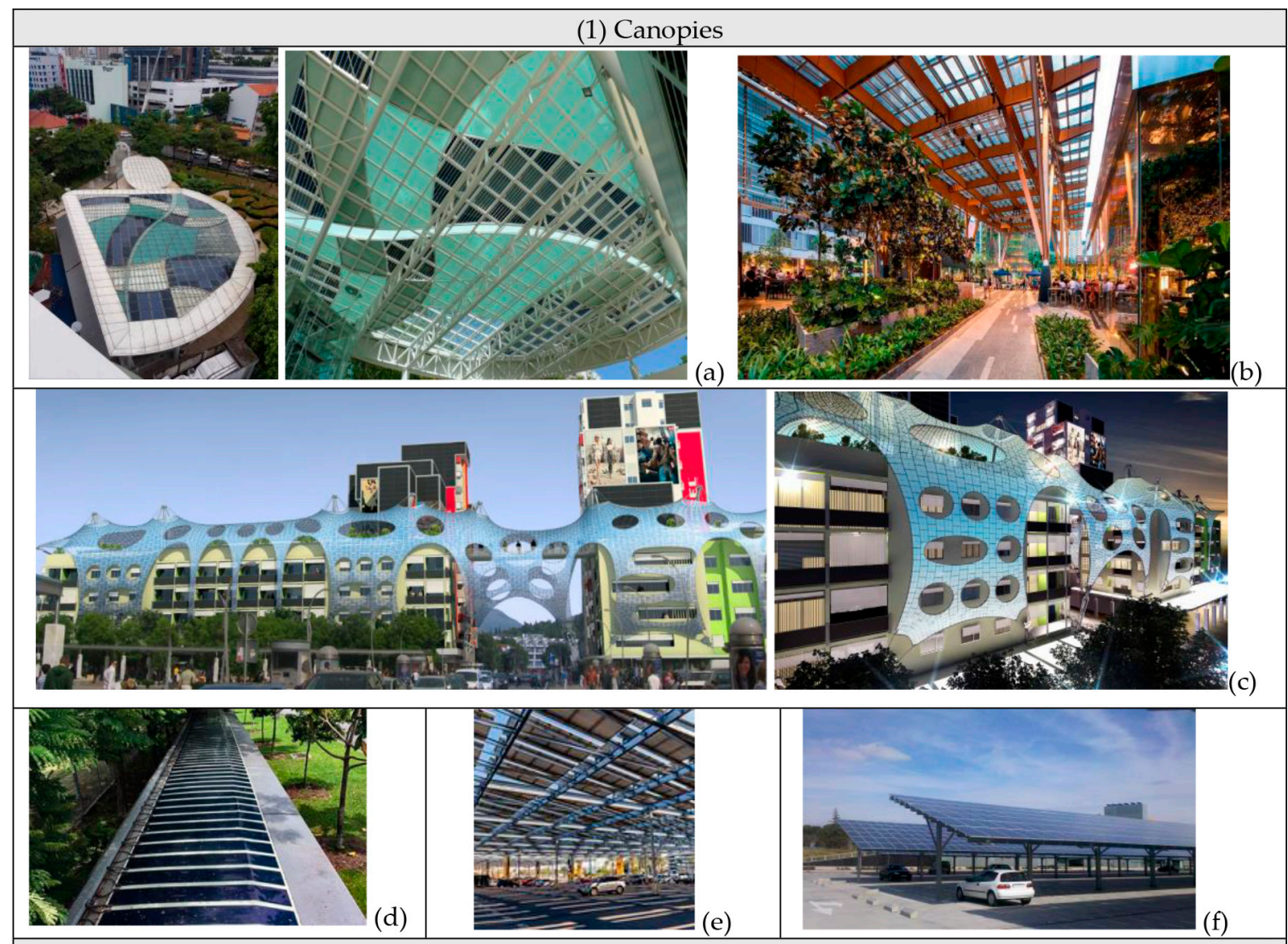

(2) Urban equipment
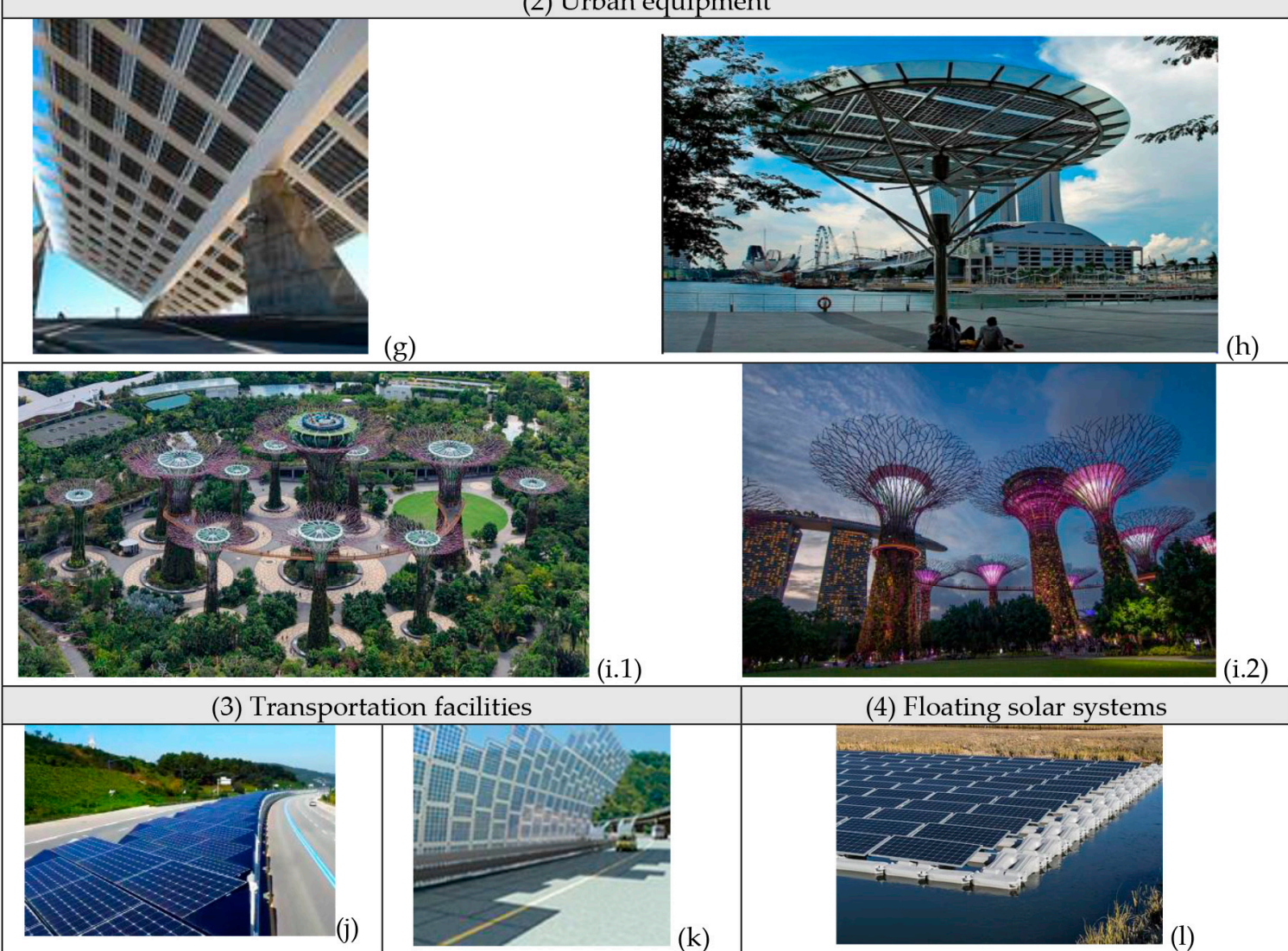

(i.1)

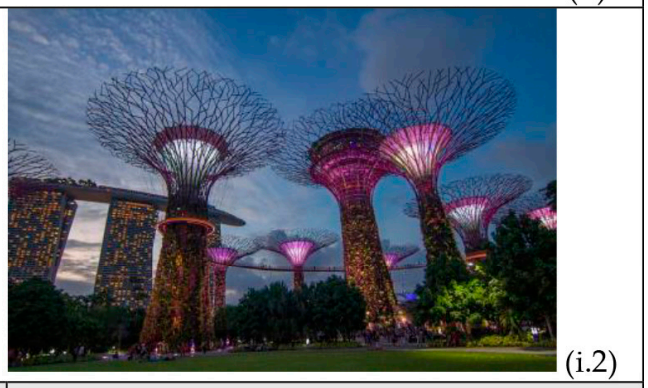

(4) Floating solar systems
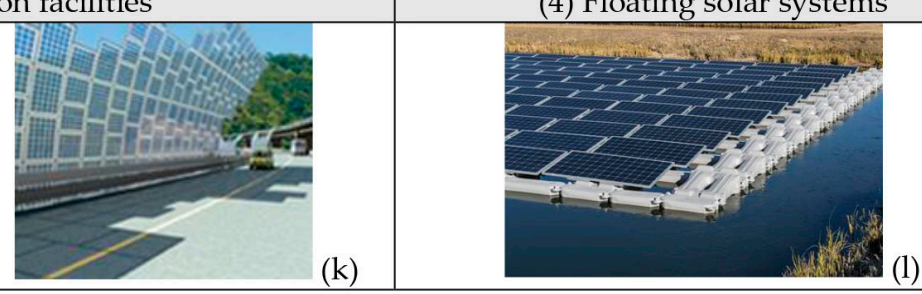

Figure 8. Integration of PV into non-building structures: (a) Canopy-City Square Mall Sunken Plaza, Singapore, installed by Phoenix Solar Pte Ltd.; (b) Tanjong Pagar PV pergola, Singapore (by Onyx Solar [152]); (c) PV structure, design concept 
developed for the central town square of Podgorica, Montenegro City (design concept by Vesna Kosorić in collaboration with Soleks d.o.o. and the City of Podgorica); (d) walkway canopy, Heliatek + vTrium Energy Pte. Ltd., Red Dot Power [153]; (e) PV panels over parking lot ("Solar Panels Covering Parking Lot-Arizona State University, Tempe", by Tony Webster, 2020, CC BY-SA 2.0 [154]); (f) parking canopies—canopy at the Autonomous University of Madrid (UAM), Spain ("PV Solar parking", by Hanjin, 2013, CC-BY-SA-3.0 [155]); (g) PV pergola-Solar Pergola, Barcelona ("Solar Pergola, Barcelona", by Max D, 2008, CC BY 2.0 [156]); (h) Waterfront Promenade Breeze Shelter (by Cripton Environmental Engineering(S) Pte Ltd. [157]; (i.1) aerial view of Supertrees in Gardens by the Bay, Singapore ("Singapore Supertree-Grove-in-The-Gardens-03", by CEphoto, Uwe Aranas, 2015, CC BY-SA 3.0 [158]); (i.2) a night view of Supertrees in Gardens by the Bay, Singapore (“2016-04-03 Supertree Grove, Gardens by the Bay 15”, Maksym Kozlenko, 2016, CC-BY-SA-4.0 [159]); (j) covered bicycle paths, a highway in Korea [160]; (k) acoustic barrier (design concept by author: Vesna Kosorić); (1) floating solar systemWalden Floating PV ("Walden Floating PV", by National Renewable Energy Lab/Dennis Schroeder, 2018, CC BY-NC-ND 2.0 [161]). Photo Credit for: (a) Christophe Inglin, Energetix Pte Ltd. [121].

\section{(4) Floating solar systems.}

A solution for countries with land constraints but lots of water areas, floating solar systems (see Figure 81), already seen as a "third pillar" of solar power deployment in Singapore, after ground mounted systems and rooftop PV, with the cumulative installed capacity having surpassed $1 \mathrm{GWp}$ in 2018 , have the potential to unlock $400,000 \mathrm{~km}^{2}$ of installation space on freshwater reservoirs alone and are thereby a new terawatt range opportunity for PV [78,162]. Upon completion in 2021, Singapore's largest floating solar PV system (60 megawatt-peak (MWp)) on Tengeh Reservoir will be one of the world's largest single floating solar PV systems [163].

\section{Conclusions}

Based on the findings from the first part of the study [17] and comprehensive consideration of factors related to the local PV and construction industry, as well as characteristics of the built environment, this paper proposes a holistic strategy for successful PV implementation into Singapore's built environment, consisting of the multilevel mechanism and general design frameworks.

Considering technology, processes, and stakeholders, the multilevel mechanism framework (see Figure 3) shows, in a systematic manner, a roadmap for the successful setup of eleven mechanism categories of activities and instruments which are necessary for obstaclefree and stimulating growth of PV implementation and especially BIPV projects. Relying on a survey conducted among PV experts on established mechanisms, the present study suggests that building codes (e.g., fire safety, structural safety, etc.) and initiatives and incentives related to PV / BIPV should be the highest priority for authorities, followed by assessment of BIPV / PV properties, working toward social acceptance, conducting research projects and information exchange, and education and training activities. Primarily, consolidating and facilitating fire safety requirements, i.e., design and installation criteria, to allow more design flexibility (e.g., in design of PV rooftop canopies, PV façade integrations, etc.), should be urgently considered and undertaken.

The general design framework (see Figure 4) defines (1) six main design principles, (2) general project instructions, and (3) the main design guidelines for PV integration into the built environment, which should ensure the elimination of design-related obstacles and lead to high-quality PV integration solutions. Created with the aim to provide balanced interaction of qualities related to environmental, economic, and social sustainability, besides technical soundness and economic viability, the main design principles include: compatibility and coherence with the local context, user-centered design, connecting with community and socio-cultural context, and adaptability and flexibility. For example, among other things, the design framework implies that, when applied in the form of different structures (canopies, urban equipment, etc.), PV can properly participate in all interrelated HARDware, ORGware, and SOFTware components that are crucial in shaping the urban space $[27,28]$. However, in order to achieve outstanding climate-responsive urban solutions, 
proper visual communication $[164,165]$ as well as the involvement of multidisciplinary teams will probably be needed, including landscape architects and urban designers, since "they intervene physically at various scales in the landscapes where people live, commute, and recreate" $[164,166]$. The framework promotes a good design potential of PV. Through concrete design recommendations, it points the way to architectural excellence of PV integrations, which can potentially result in better positioning and raising the reputation of PV systems within design and construction, not only in Singapore, but at the international level.

This paper emphasizes the need for rethinking and changes within common design methods and strategies in practice. In this regard, specific guidelines and instructions are given. Due to their ability to enable simultaneous evaluation of various qualitative and quantitative parameters of different solutions, the utilization of MCDA methods and tools is highly recommended. The solutions achieved with their help are not only aesthetically sophisticated, but meet both environmental and financial targets, thus serving as obvious economically viable examples, role models for solutions to come, and directly helping to break down the existing obstacles to PV and especially BIPV in Singapore [17].

The main design guidelines are given for PV integration into both buildings (see Figures 5 and 7) and non-building structures (see Figure 8), and are tabularly presented. For PV building integration, the fundaments are systematically derived for roofs and façades, covering both existing and new buildings. With defined principles, instructions, and guidelines, the design framework is intended to help the PV integration into the built environment play a key role in the reduction of fossil fuel electricity consumption, which would result not only in reduced $\mathrm{CO}_{2}$ emissions and economic gains, but also in various functional-constructive, formal-aesthetic, and other social benefits. Accordingly, PV implementation into the built environment could help the tropical island city-state achieve the national climate change targets, thus promoting a more sustainable built environment. To that end, the defined strategy includes, but is not limited to, various solutions presented through main design guidelines. Further, considering the significance of urban farming in Singapore [75], it is recommended to urgently explore and find viable technological solutions of agrivoltaic systems for implementation into Singapore's built environment.

Finally, the mutually interacting mechanism framework and general design framework (see Figure 1) should act together as a process intended to create a fertile ground for boosting BIPV and other PV integrations, including the merging of PV with the construction industry and helping to deliver high-quality PV design solutions. This implies not only stakeholder cooperation, but a sustainable process in which the whole community is involved and oriented towards achieving the set solar target of at least 2 GWp by 2030 [167-169].

Considering Singapore's enormous potential for exploring green principles in building design [170], with a true understanding of local values, potentials, and constraints, by combining technological advancements and creativity, unique and innovative PV integration solutions could be achieved. This would make the city a leader in sophisticated urban and tropical solar solutions.

Future studies can be focused on verification and optimization of proposed solutions in design guidelines, including analysis of their techno-economic performance (incl. energy yield, costs, carbon reduction, etc.) and other qualities. Further, the general design guidelines can serve as a basis for the development of frameworks which will go more into detail, covering specific types of buildings, e.g., residential, office buildings, etc., or urban open spaces, landscape, etc. Although the two frameworks are created for Singapore, they can also be applied to other cities or serve as a role model for creating tailor-made frameworks elsewhere, given that local climatic, economic, and socio-cultural context is considered. The methodology and frameworks including design principles and guidelines outlined in this paper may also provide valuable insights for other tropical, high-density, and any other regions which aim to intensify BIPV and other PV implementation into the built environment. Furthermore, in the wider international community dealing with 
sustainability and built environment, the proposed strategy emphasizes the importance of considering all three pillars of sustainability, including both quantitative and qualitative dimensions, together with proper understanding and interconnectedness of technology, processes, and stakeholders.

Author Contributions: Definition of methodology, development of frameworks, writing, visualization and review, V.K.; Project's principal investigator participated in the project administration and supervision, conceptualization of the project, definition of methodology, writing, editing and review, S.-K.L.; definition of methodology, writing and review, A.T.; writing and review, M.B.; writing and review, A.M.N. All authors have read and agreed to the published version of the manuscript.

Funding: The authors wish to acknowledge the funding support by the research project "Evaluation and Development of Energy Efficient PV Systems in Tropical Environment" [WBS: R-294000-136-720], which is funded by the NUS-CDL Tropical Technology Laboratory (T2 Lab) and City Development Limited.

Institutional Review Board Statement: Not applicable.

Informed Consent Statement: Not applicable.

Data Availability Statement: The data that support the findings of this study are available from the corresponding author upon reasonable request.

Acknowledgments: The authors would like to thank the Department of Architecture, School of Design and Environment, National University of Singapore for the support for this project. The authors would also like to thank Christophe Inglin (Energetix Pte Ltd., Singapore) and Philip Kwang (Facade Global Master Pte Ltd.) for their extraordinary professional assistance and support. The authors would also like to thank Zdravko Trivic, Daniel Sng Wei Meng, Min Hsian Saw, Ji Zhang, Edna Seah and Huajing Huang. The authors would like to thank Dejan Jevtić and Marko Kosorić for their professional assistance in the graphic preparation of the figures. The authors wish to express their sincere gratitude to all professionals in Singapore who took part in the web-survey and discussions.

Conflicts of Interest: The authors declare no conflict of interest. The funders had no role in the design of the study; in the collection, analyses, or interpretation of data; in the writing of the manuscript, or in the decision to publish the results.

\begin{abstract}
Abbreviations
BAPV—-building-applied photovoltaics; BCA—Building and Construction Authority; BIAbuilding integrated architecture; BIM—building information modeling; BIPV—building-integrated photovoltaics; CAAS-Civil Aviation Authority of Singapore; CDL-City Development Limited; CM—change management; GFA—gross floor area; EMA—Energy Market Authority; GIS—geographic information system; HDB-Housing \& Development Board; IDP—integrated design process; IEAInternational Energy Agency; KM—knowledge management; LCA—life-cycle assessment; LCC— life-cycle cost; MCDA—-multi criteria decision-analysis; MRT—Mass Rapid Transit; NUS—National University of Singapore; PV—photovoltaics; SCDF—Singapore Civil Defence Force; SERIS—Solar Energy Institute of Singapore; SHC-Solar Heating and Cooling; URA-Urban Redevelopment Authority; ZEB-Zero Energy Building.
\end{abstract}

\title{
References
}

1. Kaan, H.; Reijenga, T. Photovoltaics in an Architectural Context. Prog. Photovolt. Res. Appl. 2004, 12, 395-408. [CrossRef]

2. Zhang, T.; Wang, M.; Yang, H. A Review of the Energy Performance and Life-Cycle Assessment of Building-Integrated Photovoltaic (BIPV) Systems. Energies 2018, 11, 3157. [CrossRef]

3. Yang, R.J. Overcoming technical barriers and risks in the application of building integrated photovoltaics (BIPV): Hardware and software strategies. Autom. Constr. 2015, 51, 92-102. [CrossRef]

4. Wall, M.; Probst, M.C.C.; Roecker, C.; Dubois, M.C.; Horvat, M.; Jorgensen, O.B.; Kappel, K. Achieving Solar Energy in Architecture-IEA SHC Task 41. Energy Procedia 2012, 30, 1250. [CrossRef] 
5. Farkas, K.; Horvat, M. Report T.41.A.1. Building Integration of Solar Thermal and Photovoltaics-Barriers, Needs and Strategies. 2012. Available online: https://task41.iea-shc.org/Data/Sites/1/publications/T41A1_Survey_FinalReport_May2012.pdf (accessed on 12 February 2021).

6. Munari-Probst, M.C.; Roecker, C. Solar Energy Systems in Architecture, Integration Criteria and Guidelines. 2012. Available online: https://task41.iea-shc.org/Data/Sites/1/publications/T41DA2-Solar-Energy-Systems-in-Architecture-28March2013.pdf (accessed on 12 February 2021).

7. Farkas, K. Designing Photovoltaic Systems for Architectural Integration, Criteria and Guidelines for Product and Systems Dvelopers. 2013. Available online: https://task41.iea-shc.org/Data/Sites/1/publications/task41A3-2-Designing-PhotovoltaicSystems-for-Architectural-Integration.pdf (accessed on 12 February 2021).

8. Hagen, R.; Jørgensen, O.B. The Communication Process, Subtask C: Communication Guideline. Available online: https: //task41.iea-shc.org/Data/Sites/1/publications/T41C1-CommunicationsGuide-2012.pdf (accessed on 12 February 2021).

9. Yang, R.J.; Zou, P.X.W. Building integrated photovoltaics (BIPV): Costs, benefits, risks, barriers and improvement strategy. Int. J. Constr. Manag. 2016, 16, 39-53. [CrossRef]

10. Curtius, H.C. The adoption of building-integrated photovoltaics: Barriers and facilitators. Renew. Energy 2018, 126, 783-790. [CrossRef]

11. Agathokleous, R.A.; Kalogirou, S.A. Status, barriers and perspectives of building integrated photovoltaic systems. Energy 2020, 191, 116471. [CrossRef]

12. Attoye, D.E.; Adekunle, T.O.; Tabet-Aoul, K.A.; Hassan, A.; Attoye, S.O. A Conceptual Framework for a Building Integrated Photovoltaics (BIPV) Educative-Communication Approach. Sustainability 2018, 10, 3781. [CrossRef]

13. Heinstein, P.; Ballif, C.; Perret-Aebi, L.-E. Building Integrated Photovoltaics (BIPV): Review, Potentials, Barriers and Myths. Green 2013, 3, 125-156. [CrossRef]

14. Ballif, C.; Perret-Aebi, L.-E.; Lufkin, S.; Rey, E. Integrated thinking for photovoltaics in buildings. Nat. Energy 2018,3 , 438-442. [CrossRef]

15. Lu, Y.; Chang, R.; Shabunko, V.; Yee, A.T.L. The implementation of building-integrated photovoltaics in Singapore: Drivers versus barriers. Energy 2019, 168, 400-408. [CrossRef]

16. Chang, R.; Cao, Y.; Lu, Y.; Shabunko, V. Should BIPV technologies be empowered by innovation policy mix to facilitate energy transitions? Revealing stakeholders' different perspectives using Q methodology. Energy Policy 2019, 129, 307-318. [CrossRef]

17. Lau, S.K.; Kosorić, V.; Bieri, M.; Nobre, A.M. Identification of Factors Influencing Development of Photovoltaic (PV) Implementation in Singapore. Sustainability 2021, 13, 2630. [CrossRef]

18. Brown, M.; Haselsteiner, E.; Apró, D.; Kopeva, D.; Luca, E.; Pulkkinen, K.-L.; Vula-Rizvanolli, B. Sustainability, Restorative to Regenerative. COST Action CA16114 RESTORE, Working Group One Report: Restorative Sustainability. 2018. Available online: https:/ / www.eurestore.eu/wp-content/uploads/2018/04/Sustainability-Restorative-to-Regenerative.pdf (accessed on 10 April 2021).

19. Golić, K.; Kosorić, V.; Lau, S.K. A Framework for Early Stages of Socially Sustainable Renovation of Multifamily Buildings with Occupants' Participation. Sustainability 2020, 12, 8823. [CrossRef]

20. Mohtadi, T. The Complementarity of Improving Quality of Life and Reducing Environmental Footprints in Urban Spaces: The Argument for 'Hedonistic Sustainability'. Consilience 2016, 16, 14-28. Available online: https: / /journals.library.columbia.edu/ index.php/consilience/article/view/4690/2115 (accessed on 10 April 2021).

21. Bjarke, I. Hedonistic Sustainability (Lecture); KTH School of Architecture: Stockholm, Sweden, 2012. Available online: https: //www.youtube.com/watch?v=PpMDkQbye0A (accessed on 10 March 2020).

22. Eco-Business. Available online: https://www.eco-business.com/news/singapores-10-year-journey-in-urban-solar/ (accessed on 12 January 2020).

23. Existing Building Retrofit, guide published by The Centre for Sustainable Buildings and Construction, Building and Construction Authority. Available online: https://www.bca.gov.sg/GreenMark/others/existingbldgretrofit.pdf/ (accessed on 15 July 2020).

24. Building Energy Effciency R \& D Roadmap. 2013. Available online: https:/ /www.nccs.gov.sg/docs/default-source/defaultdocument-library/building-energy-efficiency-r-and-d-roadmap.pdf (accessed on 15 October 2020).

25. BCA Centre for Sustainable Buildings Ltd. Available online: http:/ / www.csb.sg/default.html/ (accessed on 7 July 2020).

26. Consortium Led by the Solar Energy Research Institute of Singapore (SERIS). "UPDATE of the Solar Photovoltaic (PV) Roadmap for Singapore", Solar Energy Research Institute of Singapore. 2020. Available online: https://www.seris.nus.edu.sg/doc/ publications/Update-of-the-Solar-Roadmap-for-Singapore-(March-2020).pdf (accessed on 2 May 2021).

27. Cho, I.S.; Heng, C.-K.; Trivic, Z. Re-Framing Urban Space: Urban Design for Emerging Hybrid and High-Density Conditions; Routledge: New York, NY, USA, 2015.

28. Cho, I.S.; Trivic, Z.; Nasution, I. Towards an Integrated Urban Space Framework for Emerging Urban Conditions in High-Density Context. J. Urban Des. 2015, 20, 147-168. [CrossRef]

29. Singapore Green Plan 2030. Available online: https:/ / www.greenplan.gov.sg/ (accessed on 28 May 2021).

30. Nastasi, B.; Di Matteo, U. Solar Energy Technologies in Sustainable Energy Action Plans of Italian Big Cities. Energy Procedia 2016, 101, 1064-1071. [CrossRef]

31. Lobaccaro, G.; Croce, S.; Lindkvist, C.; Probst, M.M.; Scognamiglio, A.; Dahlberg, J.; Lundgren, M.; Wall, M. A cross-country perspective on solar energy in urban planning: Lessons learned from international case studies. Renew. Sustain. Energy Rev. 2019, 108, 209-237. [CrossRef] 
32. Freitas, S.; Brito, M.C. Solar façades for future cities. Renew. Energy Focus 2019, 31, 73-79. [CrossRef]

33. Betsill, M.M.; Bulkeley, H. Cities and the multilevel governance of global climate change. Glob. Gov. 2006, 12, 141-159. [CrossRef]

34. Reckien, D.; Flacke, J.; De Gregorio-Hurtado, S.; Salvia, M.; Heidrich, O.; Dawson, R.J.; Olazabal, M.; Foley, A.; Orru, H.; Geneletti, D.; et al. Urban climate change response and the impact of climate networks in Europe. In Understanding Cities: Advances in Integrated Assessment of Urban Sustainability, Final Report of COST Action TU0902; Dawson, R.J., Wyckmans, A., Heidrich, O., Köhler, J., Dobson, S., Feliu, E., Eds.; Centre for Earth Systems Engineering Research (CESER): Newcastle, UK, 2014; pp. $45-52$.

35. Delponte, I.; Schenone, C. RES Implementation in Urban Areas: An Updated Overview. Sustainability 2020, 12, 382. [CrossRef]

36. Martins, V.W.B.; Rampasso, I.S.; Anholon, R.; Quelhas, O.L.G.; Leal-Filho, W. Knowledge management in the context of sustainability: Literature review and opportunities for future research. J. Clean. Prod. 2019, 229, 489-500. [CrossRef]

37. Thakur, V.; Mangla, S.K. Change management for sustainability: Evaluating the role of human, operational and technological factors in leading Indian firms in home appliances sector. J. Clean. Prod. 2019, 213, 847-862. [CrossRef]

38. SCDF. Available online: https:/ / www.scdf.gov.sg/firecode/table-of-content/chapter-10-requirements-for-special-installations / clause-10.2 (accessed on 15 April 2021).

39. Building and Construction Authority (BCA). GREEN Handbook: Photovoltaic (PV) Systems in Buildings. Singapore. 2008. Available online: https:/ /www.bca.gov.sg/GreenMark/others/pv_guide.pdf (accessed on 14 December 2019).

40. BCA; EMA. Handbook for Solar Photovoltaic (PV) Systems. Singapore. 2011. Available online: https:/ / www.pseau.org/outils / ouvrages/bca_ema_handbook_for_solar_photovoltaic_pv_systems_2011.pdf (accessed on 14 December 2019).

41. Pellegrino, M.; Flaminio, G.; Graditi, G. Testing and standards for new BIPV products. In Proceedings of the IECON 2013, 39th Annual Conference IEEE Industrial Electronics Society, Vienna, Austria, 10-13 November 2013; pp. 8127-8132. [CrossRef]

42. Falvo, M.C.; Capparella, S. Safety issues in PV systems: Design choices for a secure fault detection and for preventing fire risk. Case Stud. Fire Saf. 2015, 3, 1-16. [CrossRef]

43. Osseweijer, F.J.W.; van den Hurk, L.B.P.; Teunissen, E.J.H.M.; van Sark, W.G.J.H.M. A comparative review of building integrated photovoltaics ecosystems in selected European countries. Renew. Sustain. Energy Rev. 2018, 90, 1027-1040. [CrossRef]

44. Mah, D.N.-.Y.; Wang, G.; Lo, K.; Leung, M.K.H.; Hills, P.; Lo, A.Y. Barriers and policy enablers for solar photovoltaics (PV) in cities: Perspectives of potential adopters in Hong Kong. Renew. Sustain. Energy Rev. 2018, 92, 921-936. [CrossRef]

45. Lau, S.Y.; Chen, T.; Zhang, X.; Xue, X.; Lau, S.K.; Khoo, Y.S. A new approach for the project process: Prefabricated building technology integrated with photovoltaics based on the BIM system. In Proceedings of the IOP Conference Series: Earth and Environmental Science, Tokyo, Japan, 6-7 August 2019; Volume 294. [CrossRef]

46. Ng, P.K.; Mithraratne, N.; Kua, H.W. Energy analysis of semi-transparent BIPV in Singapore buildings. Energy Build. 2013, 66, 274-281. [CrossRef]

47. Lau, S.K.; Zhao, Y.; Lau, S.S.Y.; Yuan, C.; Shabunko, V. An Investigation on Ventilation of Building-Integrated Photovoltaics System Using Numerical Modeling. J. Sol. Energy Eng. 2020, 142. [CrossRef]

48. Shabunko, V.; Reindl, T. Measurement of solar heat gain coefficient for semi-transparent building-integrated photovoltaics in the tropics. In Proceedings of the 35th European Photovoltaic Solar Energy Conference and Exhibition (35th EU PVSEC), Brussels, Belgium, 24-28 September 2018.

49. Zhao, D.-X.; He, B.-J.; Johnson, C.; Mou, B. Social problems of green buildings: From the humanistic needs to social acceptance. Renew. Sustain. Energy Rev. 2015, 51, 1594-1609. [CrossRef]

50. Kosorić, V.; Lau, S.K.; Tablada, A.; Lau, S.S.Y. General model of photovoltaic (PV) integration into existing public high-rise residential buildings in Singapore-Challenges and benefits. Renew. Sustain. Energy Rev. 2018, 91, 70-89. [CrossRef]

51. Erbil, A.O. Social acceptance of the clean energy concept: Exploring the clean energy understanding of Istanbul residents. Renew. Sustain. Energy Rev. 2011, 15, 4498-4506. [CrossRef]

52. Wüstenhagen, R.; Wolsink, M.; Bürer, M.J. Social acceptance of renewable energy innovation: An introduction to the concept. Energy Policy 2007, 35, 2683-2691. [CrossRef]

53. Ribeiro, F.; Ferreira, P.; Araújo, M.; Braga, A.C. Public opinion on renewable energy technologies in Portugal. Energy 2014, 69, 39-50. [CrossRef]

54. Tablada, A.; Kosorić, V.; Huajing, H.; Chaplin, I.K.; Lau, S.K.; Yuan, C.; Lau, S.S.Y. Design optimisation of productive façades: Integrating photovoltaic and farming systems at the Tropical Technologies Laboratory. Sustainability 2018, 10, 3762. [CrossRef]

55. Kosorić, V.; Huang, H.; Tablada, A.; Lau, S.-K.; Tan, H.T.W. Survey on the social acceptance of the productive façade concept integrating photovoltaic and farming systems in high-rise public housing blocks in Singapore. Renew. Sustain. Energy Rev. 2019, 111, 197-214. [CrossRef]

56. Tablada, A.; Kosorić, V.; Huang, H.; Lau, S.S.Y.; Shabunko, V. Architectural quality of the productive façades integrating photovoltaic and vertical farming systems: Survey among experts in Singapore. Front. Archit. Res. 2020, 9, 301-318. [CrossRef]

57. International Energy Agency. World Energy Investment 2020: Executive Report; IEA Publications: Paris, France, 2020.

58. Department of Architecture, School of Design and Environment, National University of Singapore. Available online: https: //www.sde.nus.edu.sg/arch/research/technologies/tropical-technologies-laboratory/ (accessed on 20 January 2020).

59. Zero Energy Building @ BCA Academy. Available online: https:/ /www.bca.gov.sg/zeb/ (accessed on 20 January 2020).

60. Wittkopf, S.; Seng, A.K.; Poh, P.; Pandey, A. BIPV Design for Singapore Zero-Energy Buildings. In Proceedings of the 25th Conference on Passive and Low Energy Architecture (PLEA), Dublin, Ireland, 22-24 October 2008. 
61. Van Mierlo, B. Convergent and divergent learning in photovoltaic pilot projects and subsequent niche development. Sustain. Sci. Pract. Policy 2012, 8, 4-18. [CrossRef]

62. Chan, P.C.; Darko, A.; Ameyaw, E.E.; Owusu-Manu, D.G. Barriers affecting the adoption of green building technologies. J. Manag. Eng. 2017, 33. [CrossRef]

63. Swiss BiPV Competence Centre. Available online: www.bipv.ch (accessed on 10 December 2019).

64. Centre of Excellence for Building-Integrated PV (BIPV) at SERIS. Available online: www.bipv.sg (accessed on 8 July 2020).

65. Kosoric, V.; Wittkopf, S.; Huang, Y. Testing a design methodology for building integration of photovoltaics (PV) using a PV demonstration site in Singapore. Archit. Sci. Rev. 2011, 54, 192-205. [CrossRef]

66. Attoye, D.E.; Aoul, K.A.T.; Hassan, A. A review on building integrated photovoltaic façade customization potentials. Sustainability 2017, 9, 2287. [CrossRef]

67. Designing Buildings Wiki. Available online: https://www.designingbuildings.co.uk/wiki/Context (accessed on 10 April 2021).

68. Urban Design Guidelines for Victoria. Available online: https://www.urban-design-guidelines.planning.vic.gov.au/toolbox/ glossary (accessed on 10 April 2021).

69. Bhuyan, M.R. Architecture and its Urban Context: Place, Path and People, Context: Design, Architecture, Culture 2016, Contextbd, January. Available online: https://contextbd.com/architecture-and-its-urban-context-place-path-and-people (accessed on 10 February 2020).

70. Tuan, Y.F. Topophilia-A Study of Environmental Perception Attitudes and Values; Columbia University Press: New York, NY, USA, 1990.

71. Oliveira, J.A.; Roca, Z.; Leitão, N. Territorial Identity and Development: From Topophilia to Terraphilia. Land Use Policy 2010, 27, 801-814. [CrossRef]

72. Blizzard, J.L.; Klotz, L.E. A framework for sustainable whole systems design. Des. Stud. 2012, 33, 456-479. [CrossRef]

73. Bozovic-Stamenovic, R. A supportive healthful housing environment for ageing: Singapore experiences and potentials for improvements. Asia Pac. J. Soc. Work Dev. 2015, 25, 198-212. [CrossRef]

74. Frattolillo, A.; Canale, L.; Ficco, G.C.; Mastino, C.; Dell'Isola, M. Potential for Building Façade-Integrated Solar Thermal Collectors in a Highly Urbanized Context. Energies 2020, 13, 5801. [CrossRef]

75. Zulkifli, M. A MEWR Trilogy: Our Food and Environmental Stories Develop from Our Water Story. Singapore, Ministry of the Environment and Water Resources. Available online: https:/ /www.mse.gov.sg/resource-room/category/2019-03-07-speech-atthe-committee-of-supply-debate/ (accessed on 2 May 2021).

76. National Parks Board (NParks) of Singapore. Available online: https://www.nparks.gov.sg/about-us / city-in-nature (accessed on 24 November 2020).

77. The Straits Times. Sembcorp to Build Singapore's Largest Floating Solar Farm Covering 45 Football Fields. Available online: https:/ / www.straitstimes.com/singapore/environment/sembcorp-to-build-singapores-largest-floating-solar-farm-covering45-football (accessed on 15 June 2020).

78. World Bank Group; ESMAP; SERIS. Where Sun Meets Water: Floating Solar Market Report; World Bank: Washington, DC, USA, 2019. Available online: https:/ / documents1.worldbank.org/curated/en/579941540407455831/pdf/Floating-Solar-Market-ReportExecutive-Summary.pdf (accessed on 10 January 2021).

79. Singapore Standards Council. SINGAPORE STANDARD Photovoltaic (PV) Module Safety Qualification-Part 1: Requirements for Construction; Enterprise Singapore: Singapore, 2015.

80. Singapore Standards Council. SINGAPORE STANDARD Photovoltaic (PV) Module Safety Qualification-Part 2: Requirements for Testing; Enterprise Singapore: Singapore, 2020.

81. Lafarge Holcim Foundation for Sustainable Construction. Available online: https://www.lafargeholcim-foundation.org/about/ target-issues/resource-and-environmental-performance-planet (accessed on 7 April 2021).

82. Sellers, B.C.; Fiore, S.M. Sustainable and User-Centered: Applying Human Factors Solutions Towards Improving the Effectiveness of "Green" Buildings. Proc. Hum. Factors Ergon. Soc. Annu. Meet. 2013, 57, 550-554. [CrossRef]

83. Fiore, S.M.; Phillips, E.; Sellers, B.C. A Transdisciplinary Perspective on Hedonomic Sustainability Design. Ergon. Des. Q. Hum. Factors Appl. 2014, 22, 22-29. [CrossRef]

84. Knox, P.; Marston, S. Human Geography: Places and Regions in the Global Context, 4th ed.; Prentice Hall: Upper Saddle River, NJ, USA, 2007.

85. Haf, S.; Parkhill, K. The Muillean Gaoithe and the Melin Wynt: Cultural sustainability and community owned wind energy schemes in Gaelic and Welsh speaking communities in the United Kingdom. Energy Res. Soc. Sci. 2017, 29, 103-112. [CrossRef]

86. Soini, K.; Birkeland, I. Exploring the scientific discourse on cultural sustainability. Geoforum 2014, 51, 213-223. [CrossRef]

87. Satterfield, T.; Gregory, R.; Klain, S.; Roberts, M.; Chan, K.M. Culture, intangibles and metrics in environmental management. J. Environ. Manag. 2013, 117, 103-114. Available online: http://www.sciencedirect.com/science/article/pii/S0301479712006184 (accessed on 20 January 2020). [CrossRef]

88. Chan, K.; Satterfield, T.; Goldstein, J. Rethinking ecosystem services to better address and navigate cultural values. Ecol. Econ. 2012, 74, 8-18. [CrossRef]

89. Duxbury, N.; Jeannotte, M.S. The Role of Cultural Resources in Community Sustainability: Linking Concepts to Practice and Planning. Int. J. Sustain. Policy Pract. 2013, 8, 133-144. [CrossRef] 
90. Trivic, Z.; Mascarenhas, N.; Duong, Q.; Tan, B.K.; Padawangi, R. Bringing Arts into the Neighbourhoods: Choosing the Right Space and Strategy; National Arts Council: Singapore, 2019. Available online: https://artsforall.sg/uploads/files/Bringing\%20Arts\%20 into $\% 20$ the $\% 20$ Neighbourhoods.pdf (accessed on 10 February 2020).

91. Boesiger, M.; Bacher, J.-P. Acceptance of Building Integrated PV (BIPV) Solutions in Urban Renewal: Obstacles and Opportunities in Switzerland. Available online: https:/ / arodes.hes-so.ch/record/2616/files/Boesiger_2018_Acceptance \%20of\%20BIPV\%20 solutions\%20in\%20urban\%20renewal.pdf/ (accessed on 10 January 2021).

92. Steg, L.; Perlaviciute, G.; van der Werff, E. Understanding the human dimensions of a sustainable energy transition. Front. Psychol. 2015, 17. [CrossRef] [PubMed]

93. Hondo, H.; Baba, K. Socio-psychological impacts of the introduction of energy technologies: Change in environmental behavior of households with photovoltaic systems. Appl. Energy 2020, 87, 229-235. [CrossRef]

94. Kolarevic, B.; Parlac, V. Building Dynamics: Exploring Architecture of Change, 1st ed.; Routledge: London, UK; New York, NY, USA, 2015.

95. Guidelines on Building Integration of Photovoltaic in the Mediterranean Area. Available online: http://www.enpicbcmed.eu/sites/ default/files/guidelines_on_building_integration_of_photovoltaic_in_the_mediterranean_area.pdf/ (accessed on 5 April 2021).

96. Svetozarevic, B.; Begle, M.; Jayathissa, P.; Caranovic, S.; Shepherd, R.; Nagy, Z.; Hischier, I.; Hofer, J.; Schlueter, A. Dynamic photovoltaic building envelopes for adaptive energy and comfort management. Nat. Energy 2019, 4, 671-682. [CrossRef]

97. Chen, T.; Lau, S.Y.; Zhang, J.; Xue, X.; Lau, S.K.; Khoo, Y.S. A design-driven approach to integrate high-performance photovoltaics devices on the building façade. In Proceedings of the IOP Conference Series: Earth and Environmental Science, Tokyo, Japan, 6-7 August 2019; Volume 294.

98. Nilsson, B.; Peterson, B.; Holden, G.; Eckert, C. Design Med Omtanke: Participation and sustainability in the design of public sector buildings. Des. Stud. 2011, 32, 235-254. [CrossRef]

99. Smith, R.C.; Iversen, O.S. Participatory design for sustainable social change. Des. Stud. 2018, 59, 9-36. [CrossRef]

100. IEA SOLAR HEATING AND COOLING PROGRAMME (IEA SHC). Approaches, Methods and Tools for Solar Energy in Urban Planning. IEA SHC Task 51/Report B2; Lundgren, M., Dahlberg, J., Eds.; 2018. Available online: http://task51.iea-shc.org/Data/ Sites/1/publications/Task51_ReportB2_180815.pdf (accessed on 10 January 2021).

101. Mancini, F.; Nastasi, B. Solar Energy Data Analytics: PV Deployment and Land Use. Energies 2020, 13, 417. [CrossRef]

102. Gui, N.; Li, J.; Dong, Y.; Qiu, Z.; Jia, Q.; Gui, W.; Geert, D. BIM-based PV system optimization and deployment. Energy Build. 2017, 150, 13-22. [CrossRef]

103. Palliwal, A.; Song, S.; Tan, H.T.W.; Biljecki, F. 3D city models for urban farming site identification in buildings. Comput. Environ Urban Syst. 2021, 86, 101584. [CrossRef]

104. Xu, L.; Reed, M.; Reindl, T. CityGML and Solar Potential Analysis for Buildings in Singapore. In Proceedings of the 6th Workshop City GML Energy ADE, Ferrara, Italy, 23-25 November 2016.

105. Mahammed, I.H.; Arab, A.H.; Berrah, S.; Bakelli, Y.; Khennene, M.; Oudjana, S.H.; Fezzani, A.; Zaghba, L. Outdoor study of partial shading effects on different PV modules technologies. Energy Procedia 2017, 141, 81-85. [CrossRef]

106. Zomer, C.; Nobre, A.; Reindl, T.; Rüther, R. Shading analysis for rooftop BIPV embedded in a high-density environment: A case study in Singapore. Energy Build. 2016, 121, 159-164. [CrossRef]

107. Zomer, C.; Nobre, A.; Cassatella, P.; Reindl, T.; Rüther, R. The balance between aesthetics and performance in building-intecgrated photovoltaics in the tropics. Prog. Photovolt. 2014, 22, 744-756. [CrossRef]

108. Probst, M.C.M.; Roecker, C. Criteria and policies to master the visual impact of solar systems in urban environments: The LESO-QSV method. Sol. Energy 2019, 184, 672-687. [CrossRef]

109. Florio, P.; Peronato, G.; Perera, A.T.D.; Di Blasi, A.; Poond, K.H.; Kampf, J.H. Designing and assessing solar energy neighborhoods from visual impact. Sustain. Cities Soc. 2021, 71, 102959. [CrossRef]

110. Tablada, A.; Zhao, X. Sunlight availability and potential food and energy self-sufficiency in tropical generic residential districts. Sol. Energy 2016, 139, 757-769. [CrossRef]

111. Zhang, J.; Xu, L.; Shabunko, V.; Tay, S.E.R.; Sun, H.; Lau, S.S.Y.; Reindl, T. Impact of urban block typology on building solar potential and energy use efficiency in tropical high-density city. Appl. Energy 2019, 240, 513-533. [CrossRef]

112. Urban Redevelopemnt Authority (URA). Available online: https://www.ura.gov.sg/Corporate/Guidelines/Circulars/dc19-10 (accessed on 15 March 2021).

113. Energy Market Authority (EMA). Available online: https:/ /www.ema.gov.sg/Guide_to_Solar_PV.aspx (accessed on 15 February 2020).

114. Rosa, F. Building-Integrated Photovoltaics (BIPV) in Historical Buildings: Opportunities and Constraints. Energies 2020, 13, 3628. [CrossRef]

115. Housing \& Development Board (HDB). HDB Rolls Out Solar-Ready Roofs for Easier and Faster Installation of Solar Panels. Available online: https://www.hdb.gov.sg/cs/infoweb/about-us/news-and-publications/press-releases/01092017-hdb-rollsout-solarready-roofs (accessed on 3 June 2021).

116. Die Urban Innovation Vienna, Smart City Agency. Available online: https://smartcity.wien.gv.at/wp-content/uploads/sites/3/ 2016/12/PV-Dachgarten-11_c-IKI-AG-Ressourcenorientiertes-Bauen-BOKU-Wien-1030x728.jpg (accessed on 12 April 2021). 
117. GPA Photo Archive, Tim Brown. Solar Skylight [Photograph]. 2016. Available online: https://www.flickr.com/photos/iip-photoarchive/29244499645/in/photolist-LyeGT8-gFHcE3-C1qe7F-2jiYfko-JSDAw-BT8Jnr-B3UxpS-geHZ8a-ByhBWq-BY7qeQ-B3 UxAJ-ygyRZm-yfahYY-C1qerP-HFrNN-xZYgfg-BrUoPx-6xuKnW-yhtLKF-HFt6L-Fsc5r-cGm753-yhtLnr-cGm7f7-cGm6c9 -cGm5G3-cGm69f-cGm6Rh-cGm66E-UerL2D-2jr5X24-cGm6JQ-cGm72f-cGm6p5-cGm6TA-cGm6G1-cGm6MJ-cGm6jh-cGm5 x7-xksmh3-cGm6em-cGm5uG-cGm6uY-cGm5Mo-cGm621-cGm5JJ-cGm6DW-cGm5rh-cGm6gS-cGm5Bo?fbclid=IwAR3eKK4 7b2EX9LeSiF2oG8A3DEGcoqrZej1zikSylEIa9Pal1XE0OrH8k (accessed on 4 June 2021).

118. Colt International Limited, (Artist: Darren Civil;Colt Tollfab-Victoria). Ministry of Justice Building, Berlin [Photograph]. 2010. Available online: https://www.flickr.com/photos/coltgroup/5208943973/in/photolist-8WicyR-8Wi2Ng-8WidrH-BQeBjfBZQEBr-kEbREp-8WicnM-8WicEz-a2AhVr-a2Dcxu-9JnNd5-9r6RQA-8WkMeN-8WkMj1-8Wi79V-a2D7ZJ-8WidHP-8WmidN8WkMo7-8Wictg-9GARi3-8Wid58-9JnNdS-fKC8MB-ecvUcL-a2AjUp-9Yc52R-a2D9gJ-8Wm6Ey-9JjYGZ-9JjYyH-9JnNgNfJtxUc-a2Akzi-8Whkfz-8WidN4-8WhFSB-fKBNZH-fJNqsQ-a2DsmE-9JnNts-9r6ShG-8Wm1z3-9Yc4VX-8Wie2Z-kEdCwh-9r3 SN8-9r3Tzn-8Wi5L2-8Wm8gW (accessed on 4 June 2021).

119. David TREBOSC. Panneaux photovoltaïques [Photograph]. 2007. Available online: https://www.flickr.com/photos/trebosc/ 1276075494/in/photolist-2WLdMC-aDm2Tu-Ffqo3C-is6ZNh-99sLfX-5zEcdA-VTQNVx-bprhPa-cVSXqd-6SpjrK-efPd9N4TDHuh-9FUhzb-7nHLsb-6KPHsG-wQqJHz-6SmMep-pkRusa-c37SKj-pJ91mE-bLk6Tx-5wsNAA-aXSp6v-bkGp91-9ezkceNKTDS3-6SmPZ2-MNRdAj-dYereZ-5VVBgJ-771ZVB-bXR9wy-6Srozh-9WmtEz-5rBhik-dtNsYc-8y7W4g-aPqcUR-bWyU2raFZDfD-bJAgRi-owBWCC-nLSuA-8Wkor1-eFJ7ko-fxsT9g-6zMdtU-775Spf-wrubBM-6BCbAK (accessed on 4 June 2021).

120. David Westmore. Thin Film Flexible 003 [Photograph]. 2008. Available online: https://www.flickr.com/photos/marketsmashup/ 8597045822/in/photolist-8hB582-8hEjVW-8hEkph-8hB69p-8hEjQA-8hEkvq-8hB63P-8hEkQS-8hEkX1-8hEkj1-59nEwj-ep7Kye6G7dw-e6Asae-e6G77j-e6G7c1-e6G7aE-e6G7cY-e6G7bd-e6G79N-e6G79L-e6As9p-e6G77U-59nC2A-aDJRgW-9yLoTY-3jiKb4 -aDEZce-aDJR2E-aDJR79-aDJR8w-8ahkNn-aDEZ5M-aDJRf9-aDJR9Q-rdj6UQ-2kQFqvZ (accessed on 4 June 2021).

121. Energetix Pte Ltd. Available online: https://www.energetix.sg/ (accessed on 17 March 2020).

122. Zanetti, I.; Bonomo, P.; Frontini, F.; Saretta, E.; Verberne, G.; van der Donker, M.; Sinapis, K.; Folkerts, W. Building Integrated Photovoltaics: Product Overview for Solar Building Skins; Status Report; SUPSI, University of Applied Sciences and Arts of Southern Switzerland and SEAC (Solar Energy Application Centre). 2017. Available online: http://www.bipv.ch/images/ Report\%202017_SUPSI_SEAC_BIPV.pdf (accessed on 20 July 2020).

123. Eiffert, P. Building-Integrated Photovoltaic Designs for Commercial and Institutional Structures: A Source Book for Architects; National Renewable Energy Laboratory: Golden, CO, USA, 2000.

124. Wang, Y.; Ren, J.; Zhu, L.; Wang, Q. Influence of a building's integrated-photovoltaics on heating and cooling loads. Appl. Energy 2006, 83, 989-1003. [CrossRef]

125. Kosorić, V.; Lau, S.K.; Nobre, A.M.; Tablada, A.; Lau, S.S.Y. A comparison between photovoltaic integration onto roofs and façades of existing public high-rise residential buildings in Singapore. In Proceedings of the 13th Conference on Advanced Building Skin 2018, Bern, Switzerland, 1-2 October 2018; pp. 674-683.

126. Hanjin, BIPV Solar-Façade [Photograph], Photovoltaic Solar Facade on a Municipal Building, Social Services Centre Jose VILLARREAL, Located in Madrid (Spain). 2013. Available online: https://commons.wikimedia.org/wiki/File:BAPV_solarfacade.JPG (accessed on 4 June 2021).

127. La Citta Vita. Solar Facade [Photograph], Fondation Abbé Pierre, Paris. 2011. Available online: https://www.flickr.com/photos/ la-citta-vita/5964294206 (accessed on 4 June 2021).

128. Generalova, E.; Generalov, V. Building-Integrated Photovoltaics Technology for the Facades of High-Rise Buildings. In Energy Management of Municipal Transportation Facilities and Transport; Murgul, V., Pasetti, M., Eds.; Springer: Cham, Switzerland, 2018; Volume 983.

129. Ertex Solartechnik GmbH. Available online: https:/ /www.ertex-solar.at/fileadmin/user_upload/ReferenzenNeu/Fassade/ VSG/AT_FACADE_Fronius_Pettenbach_VSG.pdf (accessed on 4 June 2021).

130. Colt International Limited. One River Terrace (Battery Park), NY [Photograph]. 2007. Available online: https:/ / www.flickr.com/ photos/coltgroup/5925218139/in/album-72157626111309307/ (accessed on 4 June 2021).

131. Littleha. Taipei Public Library Solar LEO House BIPV 20110207 [Photograph]. 2011. Available online: https://commons. wikimedia.org/wiki/File:Taipei_Public_Library_Solar_LEO_House_BIPV_20110207.jpg (accessed on 4 June 2021).

132. Pöllö. Solar panels integrated in a block of flats in Viikki Helsinki Finland [Photograph]. 2008. Available online: https: //commons.wikimedia.org/wiki/File:Solar_panels_integrated_in_a_block_of_flats_in_Viikki_Helsinki_Finland.jpg (accessed on 4 June 2021).

133. Betancur, J. Multitasking Façade: How to Combine BIPV with Passive Solar Mitigation Strategies in a High-Rise Curtain Wall System. Int. J. High-Rise Build. 2017, 6, 307-313. [CrossRef]

134. Kiss + Cathcart. Available online: https://kisscathcart.com/integrated_agriculture.html (accessed on 10 May 2021).

135. Saber, E.M.; Lee, S.E.; Manthapuri, S.; Wang, Y.; Deb, C. PV (photovoltaics) performance evaluation and simulation-based energy yield prediction for tropical buildings. Energy 2014, 71, 588-595. [CrossRef]

136. Ong, B.Q.; Tablada, A. Investigating optimal BIPV energy yield in consideration of daylight and thermal performance in residential buildings. In Proceedings of the 33rd Conference on Passive and Low Energy Architecture (PLEA), Edinburgh, UK, 2-5 July 2017. 
137. EIA. Annual Energy Review. 2011. Available online: https://www.eia.gov/totalenergy/data/annual/pdf/aer.pdf (accessed on 20 January 2020).

138. El Gindi, S.; Abdin, A.R.; Hassan, A. Building integrated Photovoltaic Retrofitting in office buildings. Energy Procedia 2017, 115, 239-252. [CrossRef]

139. Zhang, X.; Lau, S.-K.; Lau, S.S.Y.; Zhao, Y. Photovoltaic integrated shading devices (PVSDs): A review. Sol. Energy 2018, 170, 947-968. [CrossRef]

140. Ling, T.-Y.; Chiang, Y.C. Well-being, health and urban coherence-advancing vertical greening approach toward resilience: A design practice consideration. J. Clean. Prod. 2018, 182, 187-197. [CrossRef]

141. Draper, C.; Freedman, D. Review and analysis of the benefits, purposes, and motivations associated with community gardening in the United States. J. Community Pract. 2010, 18, 458-492. [CrossRef]

142. Harris, E. The role of community gardens in creating healthy communities. Aust. Plan. 2009, 46, 24-27. [CrossRef]

143. Gaidon, B.; Kann, H.; Munro, D. Photovoltaics in the Urban Environment: Lessons Learnt from Large-Scale Pojects; Earthscan: London, UK; Sterling, VA, USA, 2009.

144. Prasad, D.; Snow, M. Designing with Solar Power: A Source Book for Building Integrated Photovoltaics (BIPV); Routledge: London, UK, 2014. [CrossRef]

145. Andersson, M.; Romero, M.A.; Johannesson, C.M. (Eds.) PV in Non Building Structures-A Design Guide. 2001. Available online: https:/ / iea-pvps.org/wp-content/uploads/2020/01/rep7_02.pdf (accessed on 20 January 2021).

146. Bazik, D. Relacijski Prostor Grada: Projekat: Tekst: Realizacija; Arhitektonski Fakultet Univerziteta: Belgrad, Serbia, 2008.

147. Vukmirovic, M.; Gavrilovic, S.; Stojanovic, D. The Improvement of the Comfort of Public Spaces as a Local Initiative in Coping with Climate Change. Sustainability 2019, 11, 6546. [CrossRef]

148. Hajep, M.; Reijndorp, A. New Public Domain: Analysis and Strategy; NAi Publishers: Rotterdam, The Netherlands, 2001.

149. BBC. Available online: https://www.bbc.com/storyworks/travel/garden-of-wonders/gardens-by-the-bay (accessed on 15 April 2021).

150. Luther, J.; Reindl, T. "Solar Photovoltaic (PV) Roadmap for Singapore”, Solar Energy Research Institute of Singapore. 2014. Available online: https://www.nccs.gov.sg/docs/default-source/default-document-library/solar-photovoltaic-roadmap-forsingapore-a-summary.pdf (accessed on 12 January 2021).

151. Krstić-Furundžić, A.; Scognamiglio, A.; Devetaković, M.; Frontini, F.; Sudimac, B. Trends in integration of Photovoltaic facilities into built environment. In Conference Procedings of the 5th International Academic Conference on Places and Technologies; KrstićFurundžić, A., Vukmirović, M., Vaništa-Lazarvić-Đukić, A., Eds.; University of Belgrade-Faculty of Architecture: Belgrade, Serbia, 2018; pp. 375-389.

152. Onyx Solar. Tanjong Pagar Photovoltaic Canopy. Available online: https://www.onyxsolar.com/tanjong-pagar (accessed on 15 January 2020).

153. Heliatek. Available online: https:/ / www.heliatek.com/de/referenzen/ (accessed on 4 June 2021).

154. Tony Webster. Solar Panels Covering Parking Lot-Arizona State University, Tempe [Photograph]. 2020. Available online: https:/ / www.flickr.com/photos/diversey/49376055688/in/photolist-5cYDjG-8YX6JA-6gjgXt-T258A3-ndPTkx-5J4HHG2ER4JU-49kbx2-oerbBX-24RMDSe-8f8Y1z-8f8XKk-8f8XRF-8fceWd-3zt1s-8HdZmp-8f8XFK-T258uS-Q9yv3F-fJGpFs-cN6URERaBDwV-XqTBep-8YU4hM-8YX4J7-2iecc7Y-5peGWB-eWpxhk-64qxa-dNsQut-25p2MK1-2jeWjg7-oSCRxQ-8YX43m-zdHTdi7arGwZ-xbbmFk-XYnK6g-E2Ve9H-2hNk111-dRG3gg-xAPt77-cVC83m-auYcrE-49kaFR-mbfCj-E2Yqn8-ftK69m-7arHrp4oeXX/ (accessed on 4 June 2021).

155. Hanjin. PV Solar Parking [Photograph], PV Solar Parking Canopy at the Autonomous University of Madrid (UAM), Spain. 2013. Available online: https:/ / commons.wikimedia.org/wiki/File:PV_solar_parking.jpg (accessed on 4 June 2021).

156. Max, D. Solar Pergola, Barcelona [Photograph]. 2008. Available online: https://www.flickr.com/photos/stnsi/4508272135/in/ photolist-7So5eV-7SoC86-7SrGKS-7SnUWn-7SrLx1-7SnY76-7So1Tp-7SrDnd-7Sodux-7Srb9N-7SoT5R-7SoPCa-7SrrEb-7Sohfk7SoGdz-7SrQQj-7SoK4F-7SnVxv-5nDCEn-asTrpc-4H5c2W-breDzz-Egp3se-EnKQtN-EFETwz-EgoSPB-Ne3SdQ-DSurE8-R4 nreh-Ne3QM3-osBi72-p12SN3-DSuuVM-H3vBtm-DS9Ugf-Egp2gX-HVk6rU-EMyxMW-EFENTg-QHkob5-EFEESX-EFEN4kEgp4uz-DS9Sk1-HPDzu3-H3vF6m-R4nqBq-8tDwMW-HVk64u-HPDxFJ (accessed on 4 June 2021).

157. Cripton Environmental Engineering(S) Pte Ltd. Waterfront Promenade Breeze Shelter. Available online: https://cripton.com.sg/ project/waterfront-promenade-breeze-shelter/\#.YIM-1egzbIU (accessed on 12 April 2021).

158. CEphoto, Uwe Aranas. Singapore: Supertree Grove in The Gardens by the Bay [Photograph]. 2015. Available online: https: //commons.wikimedia.org/wiki/File:Singapore_Supertree-Grove-in-The-Gardens-03.jpg (accessed on 4 June 2021).

159. Maksym Kozlenko. 2016-04-03 Supertree Grove, Gardens by the Bay 15 [Photograph]. 2016. Available online: https://commons. wikimedia.org/wiki/File:2016-04-03_Supertree_Grove,_Gardens_by_the_Bay_15.jpg (accessed on 4 June 2021).

160. Inhabitat. This Bike Lane in Korea Is Topped with 20 Miles of Solar Panels. Available online: https:/ /inhabitat.com/could-thissolar-powered-bike-lane-in-korea-inspire-other-countries-to-add-one/korea-solar-bike-lane-2/ (accessed on 10 January 2020).

161. National Renewable Energy Lab (Photo by Dennis Schroeder/NREL). Walden Floating PV [Photograph]. 2018. Available online: https: / www.flickr.com/photos/nrel/31648323108/in/photolist-QdDVAq-2aXKUUR-29G5pFg-2bfppRs-2cmwu682ch26vG-2b13mvU-Mjq8ng-2cmweP2-QdDVRf-Mjq77F-2cmwq6z-28jtTT7-2aXKY6v-2b5mRaB-NAc8Ci-NWHbEG-2b13xAu2aXKEDM-2aXKyn8-MjqdAH-28jtT7s-2ch1VxW-29YV7tq-2bfpUPY-28jtTpS-28jtKKo-2b13kdy-29zXRkh-2ch1JwN-29YV8Q3 -2aXKQvF-QdDKS7-2aXKUni-MjqfMM-29YV4Xo-29zXEsf-2bfpFeS-NAc7jB-MjqfmX-28jtNzm-28jtSSj-2ch23Ad-28jtSuA-2b5 mVHV-2ch1V9Q-2b13vSj-MjqhKe-2cmwuix-2ch238E/ (accessed on 4 June 2021). 
162. Dai, J.; Zhang, C.; Lim, H.V.; Ang, K.K.; Qian, X.; Wong, J.L.H.; Tan, S.T.; Tan, S.T.; Wang, C.L. Design and construction of floating modular photovoltaic system for water reservoirs. Energy 2020, 191, 116549. [CrossRef]

163. Sembcorp Industries Ltd. Sembcorp Appointment by PUB to Build Singapore's Largest Floating Solar Farm on Tengeh Reservoir. Available online: https://www.sembcorp.com/en/media/media-releases/energy/2020/february/sembcorp-appointment-bypub-to-build-singapore-s-largest-floating-solar-farm-on-tengeh-reservoir/ (accessed on 15 June 2020).

164. Cortesão, J.; Lenzholzer, S.; Jochen, M.; Lisette, K.; Cor, J.; Jeroen, K. Visual guidelines for climate-responsive urban design. Sustain. Cities Soc. 2020, 60, 102245. [CrossRef]

165. Sheppard, S.R.J. Making climate change visible: A critical role for landscape professionals. Landsc. Urban Plan. 2015, 142, 95-105. [CrossRef]

166. Stanislav, A.; Chin, J.T. Evaluating livability and perceived values of sustainable neighborhood design: New Urbanism and original urban suburbs. Sustain. Cities Soc. 2019, 47, 101517. [CrossRef]

167. The Straits Times. Solar Panels on Rooftops or Floating on Water May Be a Common Sight Soon. Available online: https://www. straitstimes.com/singapore/environment/solar-panels-on-rooftops-or-floating-on-water-may-be-a-common-sight-soon (accessed on 25 November 2020).

168. Channel News Asia. Available online: https://www.channelnewsasia.com/news/singapore/singapore-international-energyweek-low-carbon-research-13373396 (accessed on 25 November 2020).

169. PV Magazine Australia. Available online: https://www.pv-magazine-australia.com/2020/10/31/weekend-read-singaporesolar-walks-the-talk/ (accessed on 25 November 2020).

170. Schröpfer, T. The Dense and Green Paradigm. In Dense + Green: Innovative Building Types for Sustainable Urban Architecture, 1st ed.; Müller, A., Ed.; Birkhäuser Verlag GmbH: Basel, Switzerland, 2018; pp. 12-38. 